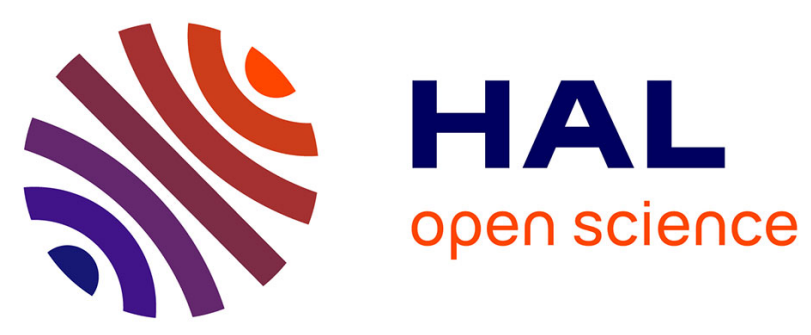

\title{
Palaeoenvironmental reconstitutions at the Carboniferous-Permian transition south of the Paris Basin, France: implications on the stratigraphic evolution and basin geometry
}

Mathilde Mercuzot, Sylvie Bourquin, Laurent Beccaletto, Céline Ducassou, Romain Rubi, Pierre Pellenard

\section{To cite this version:}

Mathilde Mercuzot, Sylvie Bourquin, Laurent Beccaletto, Céline Ducassou, Romain Rubi, et al.. Palaeoenvironmental reconstitutions at the Carboniferous-Permian transition south of the Paris Basin, France: implications on the stratigraphic evolution and basin geometry. International Journal of Earth Sciences, 2021, 110 (1), pp.9-33. 10.1007/s00531-020-01940-7 . insu-02973889

\section{HAL Id: insu-02973889 \\ https://hal-insu.archives-ouvertes.fr/insu-02973889}

Submitted on 23 Oct 2020

HAL is a multi-disciplinary open access archive for the deposit and dissemination of scientific research documents, whether they are published or not. The documents may come from teaching and research institutions in France or abroad, or from public or private research centers.
L'archive ouverte pluridisciplinaire HAL, est destinée au dépôt et à la diffusion de documents scientifiques de niveau recherche, publiés ou non, émanant des établissements d'enseignement et de recherche français ou étrangers, des laboratoires publics ou privés. 


\title{
Palaeoenvironmental reconstitutions at the Carboniferous-Permian transition south of the Paris Basin,
}

France: implications on the stratigraphic evolution and basin geometry

Mathilde Mercuzot ${ }^{\mathrm{a}}$, Sylvie Bourquin ${ }^{\mathrm{a}}$, Laurent Beccaletto ${ }^{\mathrm{b}}$, Céline Ducassou $^{\mathrm{a}}$, Romain Rubi ${ }^{\mathrm{c}}$, Pierre Pellenard ${ }^{\mathrm{d}}$

aUniv Rennes, CNRS, Géosciences Rennes - UMR 6118, F-35000, Rennes, France

${ }^{\mathrm{b}}$ BRGM, F-45060 Orléans, France

cDept. of Physical Geography and Quaternary, University of Liège, Liège, Belgium

dBiogéosciences UMR uB/CNRS 6282, Université Bourgogne Franche-Comté, 21000 Dijon, France

*corresponding author: mathilde.mercuzot@outlook.com

\section{Acknowledgments}

We are grateful to the French geological survey (BRGM) and the Bretagne region (France) for financial support (Mathilde Mercuzot's PhD). The authors also thank Christian Le Carlier de Veslud for assistance for the GoCad GeoModeller software, Sara Mullin for the English proofreading, and Thomas Voigt and Frank Scholze for their detailed comments, which have greatly improved the manuscript.

\begin{abstract}
The late Carboniferous to Permian coal-bearing Decize-La Machine Basin, and more specifically the Lucenay-lèsAix area, located south of the Paris Basin, has been investigated in order to reassess the palaeoenvironmental evolution and the basin architecture. The detailed sedimentological study has been carried out based on core data and digitised old mining data, i.e. seismic profiles and well-logs. An interpretation of well-logs without core data is proposed, based on a palaeoenvironmental interpretation from cores and their respective well-log data, and three depositional environments have been defined: an alluvial plain, an alluvial-fan, and deltaic and lacustrine environments. Correlations between wells have been performed using markers identified in seismic profiles, paired with sequence stratigraphic interpretations from well-log and core data. An evolution in seven major progradational-retrogradational stratigraphic cycles is proposed based on the evolution of the depositional environment observed at the basin scale, leading to a reconstruction of palaeogeographic maps at the Carboniferous-Permian transition. This new viewpoint shows that through time, the deposits, proximal at the base of the succession with coal preservation, become more lacustrine with the delta prograding into the basin. In
\end{abstract}


consequence, the basin evolution shows a general retrogradational trend with increasing lacustrine deposits at the top of the succession eroded by the Permian-Triassic unconformity. Therefore, the current borders of the basin in the Lucenay-lès-Aix area are not representative of those at the time of the sedimentary filling, and thus, this area could be part of a larger one, perhaps encompassing all north-eastern French Massif Central late Carboniferous to Permian basins.

\section{Keywords}

Carboniferous-Permian of Decize-La Machine Basin; sedimentological analyses; sequence stratigraphy; depositional environment; seismic and well-log data

\section{Introduction}

The Carboniferous to Permian transition is of great geological interest because it records large internal and external geodynamic variations of the Earth. This period corresponds to the transition from the end of the Variscan orogen to the breakup of Pangaea (Scotese and Langford 1995; Stampfli et al. 2013), and to the transition between the Late Palaeozoic Ice Age (LPIA) and the end-Permian to Triassic aridification (e.g. Bishop et al. 2010; Bourquin et al. 2011).

The Variscan orogen provides evidence for the collision between the southerly Gondwana and northerly Laurussia; the mountain belt was oriented E-W, and located in the Pangean equatorial to intertropical realm during the Carboniferous and Permian. In Europe, it results from the accretion of several microcontinents (e.g. Avalonia and Armorica) and intervening oceanic domains (Matte 1986; Franke et al. 2000; Lardeaux et al. 2001; Ballèvre et al. 2009; Martinez-Catalan et al. 2009), and is evidenced by high pressure-low temperature metamorphic rocks formed during subduction and nappe stacking (Paquette et al. 2017; Lotout et al. 2018). Because of the postorogenic history footprints (collapse of the reliefs, late-orogenic extension, late Alpine tectonics; Faure et al. 1995; Ballèvre et al. 2013), the geodynamic evolution of the Variscan belt is difficult to establish and is therefore not consensual (e.g. Ballèvre et al. 2014; Franke et al. 2017). The post-orogenic collapse of the thick and hot Variscan crust is reflected by high grade metamorphic domes, detachments and extensive faults reactivating ancient shear zones (Malavieille et al. 1990; Van den Driessche and Brun 1992; Burg et al. 1994). Internal Pennsylvanian (i.e. late Carboniferous) to Permian European basins, considered as pull-apart or hemi-graben basins, developed in the late orogenic extensional structural context (Ménard and Molnard 1988; Vallé et al. 1988; Van den Driessche and 
Brun 1989, 1994; Burg et al. 1990; Malavieille et al. 1990; Faure and Becq-Giraudon 1993; Faure 1995; BecqGiraudon et al. 1996; Genna et al. 1998; Choulet et al. 2012).

Paired with this tectonic context, these sedimentary basins could have also recorded the LPIA, marking the transition from a global icehouse to a greenhouse climate during the Permian. This climatic period corresponded to the latest wide-extent and long-lived glaciation on a vegetated Earth (Gastaldo et al. 1996; Michel et al. 2015). The specificity of this period is notably the lowest $\mathrm{CO}_{2}$ and highest $\mathrm{O}_{2}$ levels of the Phanerozoic (e.g. Berner 2006; Montanez et al. 2007, 2016), that lasted during dozens of millions of years, from the late Devonian to the Cisuralian-Guadalupian, i.e. early-middle Permian, (Fielding et al. 2008). The LPIA witnessed long-lived but discrete ice sheets, diachronous at the scale of Gondwana, migrating eastward from the late Devonian to the early Permian (Isbell et al. 2003; Fielding et al. 2008; López-Gamundí and Buatois 2010; Montanez and Poulsen 2013), with an apex during the Pennsylvanian-Sakmarian.

The latest Variscan tectonic stages combined with the end of the LPIA and the transition to the greenhouse climate, from humid to arid conditions (Isbell et al. 2003; Roscher and Schneider 2006; Bourquin et al. 2011; Michel et al. 2015), are the prevalent driving factors controlling the sedimentary dynamic of Western European Carboniferous to Permian basins. This is the case for French intracontinental Carboniferous-Permian basins located south of the Variscan front, in the internal zones of the mountain belt, which result from late- to post-orogenic extensional processes (Malavieille et al. 1990; Costa and Rey 1995; Faure 1995; McCann et al. 2006), and record a period of destruction of the Variscan reliefs. Some of these sedimentary basins are located south of the Paris Basin, mainly known through subsurface and mining data, such as the Decize-La Machine Basin. For this basin, sediments partly crop out at the Decize-La Machine horst, but its western, eastern and southern terminations are located under the Meso-Cenozoic sedimentary cover. The area of Lucenay-lès-Aix, located south of the Decize-La Machine horst (Fig. 1), has been exploited since 1806. The latest investigations performed in the $20^{\text {th }}$ century and up to 1986 for the mining industry, aimed to characterise the coal resources in the subsurface. Old mining reports indicate a succession of fine and coarse-grained deposits attributed to lacustrine and fluvio-lacustrine sediments, in which coal seams are interbedded. The occurrence of altered volcanic ash layers (i.e. tonsteins) and microbial deposits have been documented and tentatively used to propose intrabasin correlations (Donsimoni 1990). 


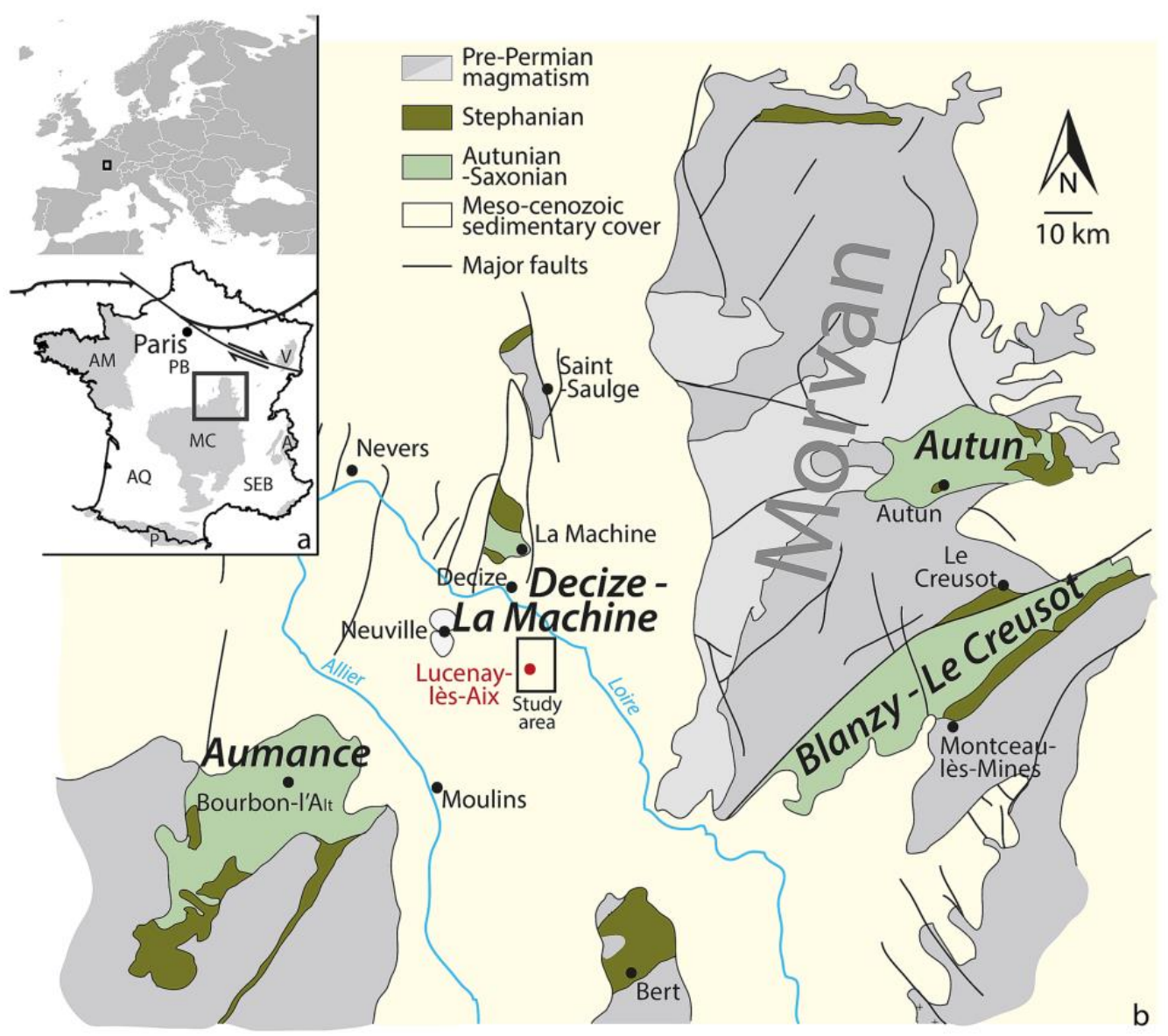

Fig. 1 Localisation of the late Carboniferous-to-Permian basins in the north-eastern Massif Central (modified from Elsass-Damon 1977). The Lucenay-lès-Aix area is located south of the outcropping Decize-

\begin{abstract}
La Machine succession. $A M$ Armorican Massif, $M C$ Massif Central, $P$ Pyrenees, $A$ Alps, $V$ Vosges, $A B$ Aquitaine Basin, $S E B$ South-East Basin, $P B$ Paris Basin
\end{abstract}

Here, we aim to reassess the sedimentary architecture and the palaeoenvironmental evolution in this area, based on updated data and methods. Stratigraphical and sedimentological re-evaluations are based on the investigation of three cored boreholes from the Lucenay area, well-logs and seismic data acquired during the 1980s. The palaeoenvironmental evolution through time is assessed through facies and facies association determination using cores analysis and electrofacies characterisation on well-logs. Supported by seismic interpretation, stratigraphic correlations between the wells are performed in the Lucenay-lès-Aix area, highlighting the sedimentary architecture of the Decize-La Machine Basin. These results are then compared with data from adjacent areas, in order to document the basin geometry and environments throughout time and space and to better constrain the Carboniferous to Permian evolution of the internal zone of the Variscan orogen.

\section{Geological setting}

\subsection{French Late Carboniferous to Permian basins cropping out south of the Paris Basin}


French Carboniferous to Permian basins are localised around the remnants of the Variscan belt, such as the Vosges, Alps, Pyrenees, Armorican Massif and Massif Central (Fig. 1a), but are also known in the subsurface below the Aquitaine Basin and South-East Basin, and below the Meso-Cenozoic cover of the Paris Basin, to the south (Beccaletto et al. 2015) and to the north-east (Donsimoni 1981). In the north-eastern part of the Massif Central, several basins are exposed (the Aumance, Autun, Decize-La Machine and Blanzy-Le Creusot basins, Fig. 1b) and, for some of them, may constitute the termination of the subsurface basins south of the Paris Basin (Beccaletto et al. 2015). Numerous lithological and palaeontological analyses were performed on these late Carboniferous to early Permian basins, which were investigated during the $19^{\text {th }}$ and $20^{\text {th }}$ centuries for coal and oil mining. The sedimentary succession in these basins is attributed to the late Pennsylvanian-early Permian (i.e. upper Westphalian, Stephanian A, B and C, Autunian and Saxonian regional sub-stages; Heckel and Clayton 2006; Menning et al. 2006; Schneider et al. 2020). The Westphalian and Stephanian are often attributed to the late Pennsylvanian, while the Autunian and Saxonian are considered to have a Permian affinity. However, it is difficult to correlate these stratigraphic units to the official marine stages because their boundaries, defined using macroflora, palynomorphs and fauna associations, are diachronous (Langiaux 1984; Broutin et al. 1986, 1990, 1999; Doubinger et al. 1979; Schneider et al. 2020). Thus, intra- and inter-basinal stratigraphic correlations based on available biostratigraphy should be cautiously considered due to large uncertainties, even when basins are separated by a short distance, due to depositional environment biases affecting macro- and microflora repartition. However, instantaneous aerial volcanic events are regularly recorded as thin tonstein deposits intercalated in the succession and could be used as correlation tools. In the French Autun and Lodève basins, such altered volcanic ash layers have been recently dated (Michel et al. 2015; Pellenard et al. 2017) by U-Pb on zircon using the chemical abrasion-isotope dilution-thermal ionisation mass spectrometry (CA-ID-TIMS) method. In the Lucenay-lès-Aix area, recent $\mathrm{U}-\mathrm{Pb}$ ages using laser ablation-inductively coupled plasma-mass spectrometry (LA-ICP-MS) have been also performed by Ducassou et al. (2019), and correlations were then tentatively applied between these three basins. A late Gzhelian to early Asselian age could be attributed to the base of the Lucenay-lès-Aix succession (299 \pm 2 Ma, Ducassou et al. 2019), which could therefore be correlated with the lower Autunian (Igornay Fm and Muse Fm) defined in the Autun Basin (299.9 \pm 0.38 Ma to 298.05 \pm 0.19 Ma; Pellenard et al. 2017), and either to a gap in the Lodève Basin (Michel et al. 2015) or to the Graissessac Fm (295.5 \pm 5.1 ; Bruguier et al. 2003). The middle of the sedimentary succession from the Lucenay-lès-Aix area yielded a $295 \pm 5$ Ma age (Ducassou et al. 2019), and could be compared either with the Tuilières-Loiras Fm and Viala Fm (293.94 \pm 0.08 Ma to 
$290.96 \pm 0.19$ Ma using CA-ID-TIMS U-Pb dating by Michel et al. 2015) or to the Graissessac Fm (295.5 \pm 5.1 ; using SIMS U-Pb dating by Bruguier et al. 2003).

\subsection{The Decize-La Machine Basin}

To the west of the Morvan Massif (Fig. 1), Palaeozoic units crop out near the localities of Saint-Saulges and Neuville (crystalline rocks), and near Decize and La Machine (sedimentary rocks), due to the activity of a postPermian fault system. The sedimentary succession of the Decize-La Machine horst, covering an area of approximately $50 \mathrm{~km}^{2}$, is composed of coarse-grained sandstones, polygenic conglomerates, shales with sandstone intercalations and black shale deposits, and shows evidence of microbial deposits and the occurrence of coal seams and tonstein layers. These sedimentary successions were exploited for coal and oil resources, leading to research being carried out in the surrounding areas to localise and characterise the amount of the potential resource. This basin extends in the subsurface under the Meso-Cenozoic cover (ca. 60 to $370 \mathrm{~m}$ in thickness) to the north, up to the Saint-Saulge horst, and more extensively to the east, west and south. However, the palaeogeographic boundaries of this basin at the time of sedimentation are not known, and it may have been connected with the Aumance Basin located to the west (Fig. 1b) (Grangeon et al. 1968; Châteauneuf and Farjanel 1989). The sedimentary succession is divided into the upper Westphalian, only found to the south-east, the Stephanian and the Autunian. However, these regional stages are biostratigraphically poorly documented in this area and may thus be only considered as lithostratigraphic units. The Stephanian and Autunian units are in stratigraphic continuity, but the Stephanian sedimentation area is more restricted compared to those of the Autunian which presents a larger extent. This indicates that the depocenters migrate and widen through time. The Triassic deposits unconformably overlie the Permian succession, following a huge erosional event. The cumulative thickness of the Palaeozoic sedimentary succession in this basin is thought to exceed $3000 \mathrm{~m}$.

The Lucenay-lès-Aix area is located approximately $15 \mathrm{~km}$ south of Decize (Fig. 1), and is characterised by a relatively flat topography, with a mean altitude close to $220 \mathrm{~m}$, peaking at $236 \mathrm{~m}$. This sub-basin was the latest to be investigated in the Decize-La Machine Basin during the French national coal resource inventory from 1981 to 1986 (Donsimoni 1990, 2006). This exploration campaign began with gravimetric investigations, with a negative Bouguer anomaly detected in the Lucenay-lès-Aix area, showing a thick sedimentary accumulation over the crystalline basement (Donsimoni, 1990, 2006). These investigations were completed with electric, seismic and magnetotelluric surveys based on rock resistivity, partially cored boreholes, and well-log data (Fig. 2a); 31 kilometres of seismic lines were shot (Fig. 2a). The crystalline basement was not reached by the wells but was 
estimated to be at a depth close to $1500 \mathrm{~m}$ (Donsimoni, 1990). The eastern edge of the sub-basin was not investigated but may be wider than the studied area. The sedimentary deposits were initially attributed to fluvial, palustrine and lacustrine environments (Donsimoni 1990) but recently reattributed to deltaic and lacustrine deposits, from the LY-F core, by Ducassou et al. (2019) (Fig. 2a); the lithostratigraphy is defined by the productive La Machine and Lucenay formations, attributed to the Stephanian B and C, and separated by a discontinuity. In these two formations, a substantial amount of coal was evidenced at depths ranging between $200 \mathrm{~m}$ and $600 \mathrm{~m}$. Above, the more detrital "Grey Autunian" and "Red Permian" formations are assumed to be in stratigraphic continuity (Donsimoni 1990, 2006). The tectonic structure of the Lucenay-lès-Aix area was defined as a hemigraben geometry, with a syn-sedimentary fault oriented $\sim \mathrm{N}-\mathrm{S}$, governing the disposition with a thick sedimentary accumulation in the western part of the basin, and limited sedimentary inputs towards the east. The subsidence was thought to be heterogeneous with time throughout this area: high and fast subsidence favoured debris flow deposits, while more moderate and regular subsidence favoured palustrine to lacustrine deposits, including coal deposits (Donsimoni 1990). 


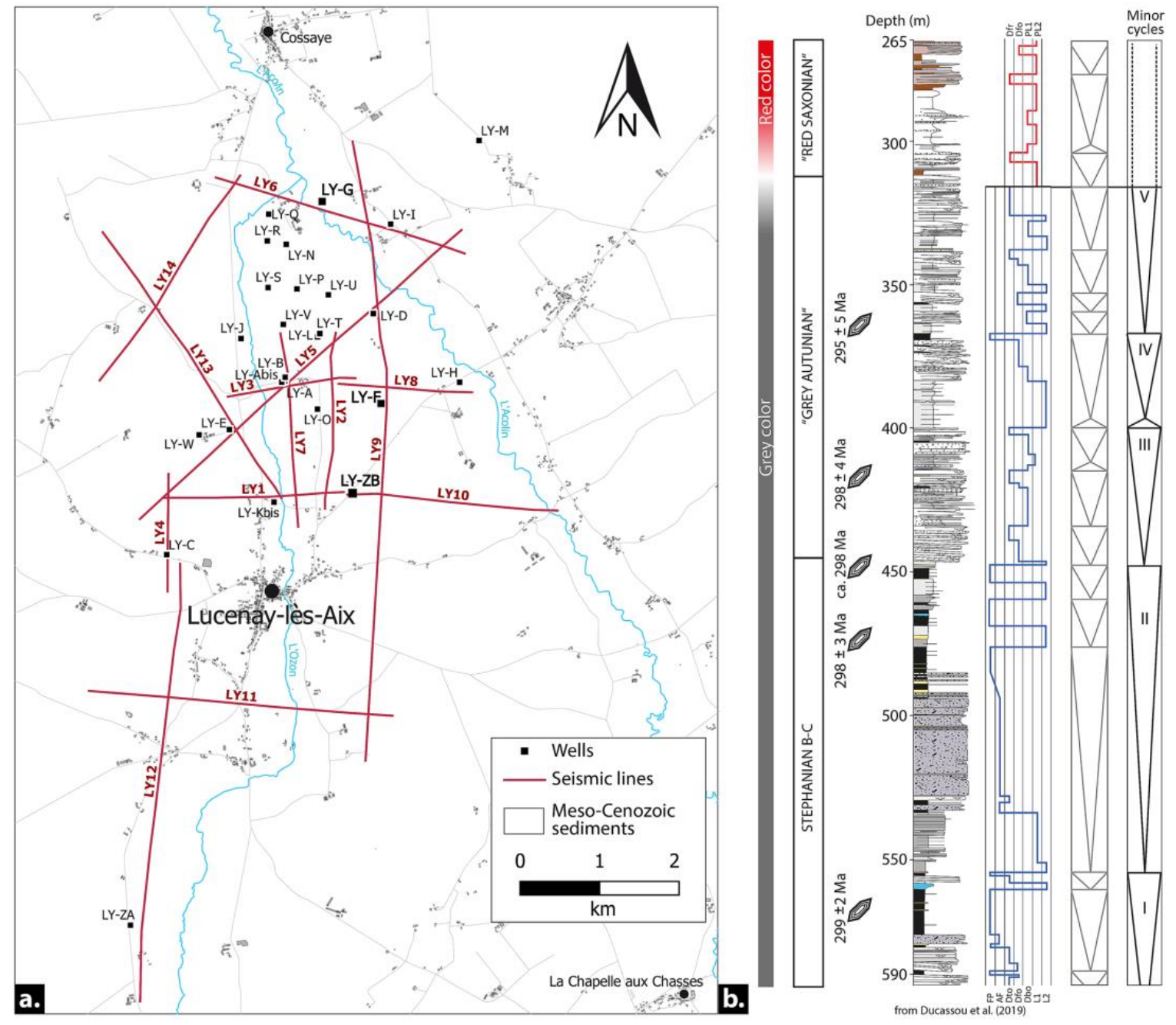

Fig. 2 a Map of the Lucenay-lès-Aix area, showing the location of the studied wells and the seismic lines. b Synthetic sedimentary column, depositional environments evolution, and stratigraphic cycles of

the LY-F core after Ducassou et al. (2019). FP floodplain, $A F$ alluvial-fan delta, $D f r$ delta frontset, $D f o$ delta foreset, $D b o$ delta bottomset, $L$ lake, $P L$ playa lake

\section{Material and methods}

\subsection{Sedimentological descriptions (facies and electrofacies)}

Among the 37 wells drilled during the exploration campaign of the Lucenay-lès-Aix area during the 1980s, only three cores are still available (property of the BRGM - French Geological Survey): the LY-F, LY-G and LY-ZB wells (Fig. 2a). The LY-F core has already been investigated and dated by Ducassou et al. (2019) (Fig. 2b). The LY-F, LY-G and LY-ZB cored boreholes were first described in this study in terms of lithology, sedimentary structure, grain composition and morphology, and colour (i.e. reflecting organic content and oxidation of the sediment). Each bed was then assigned to a sedimentary facies and to a depositional process (Table 1, 3). Finally, facies were associated to characterise the depositional environments along a depositional profile (facies associations, Table 2). 


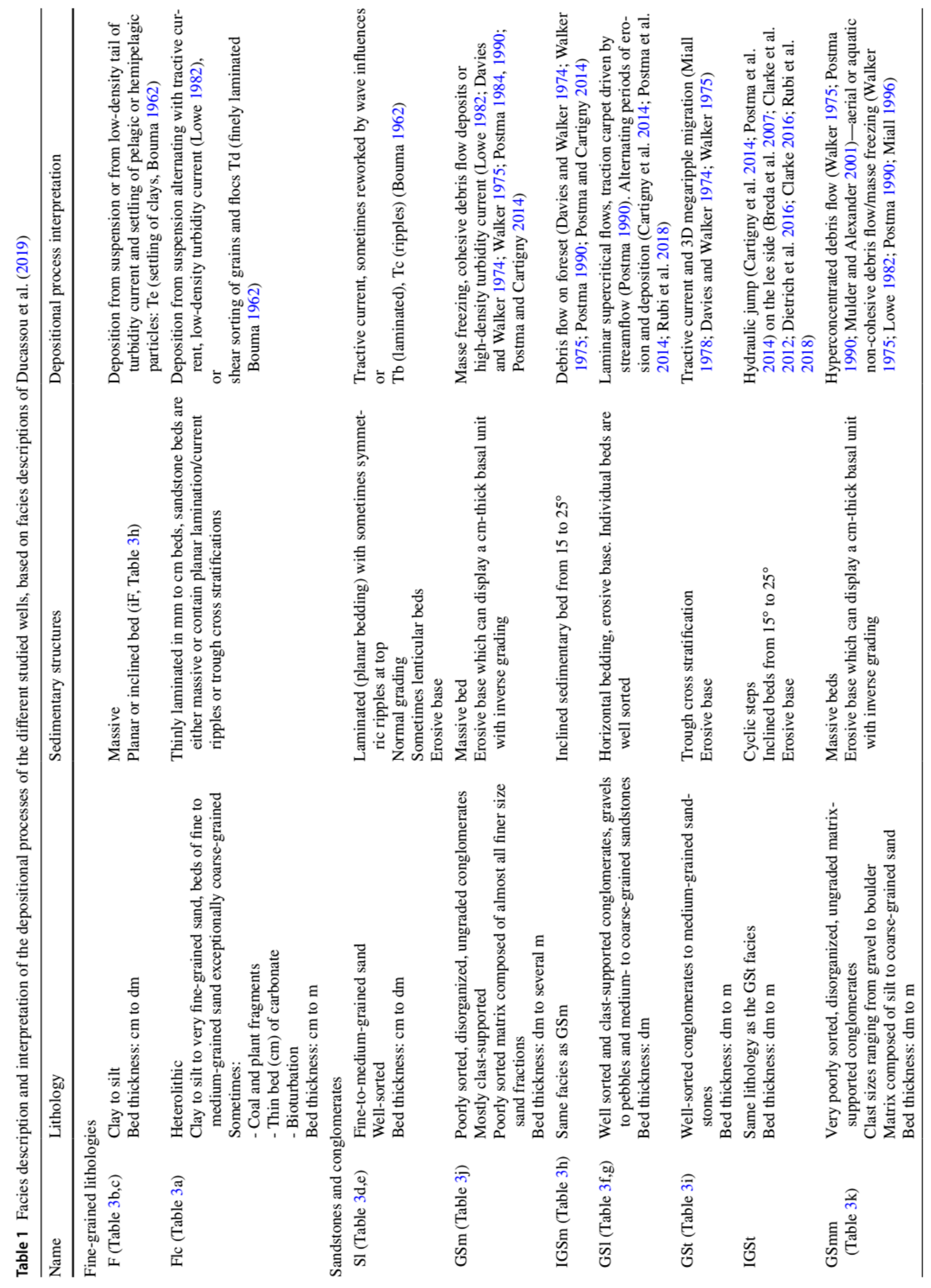



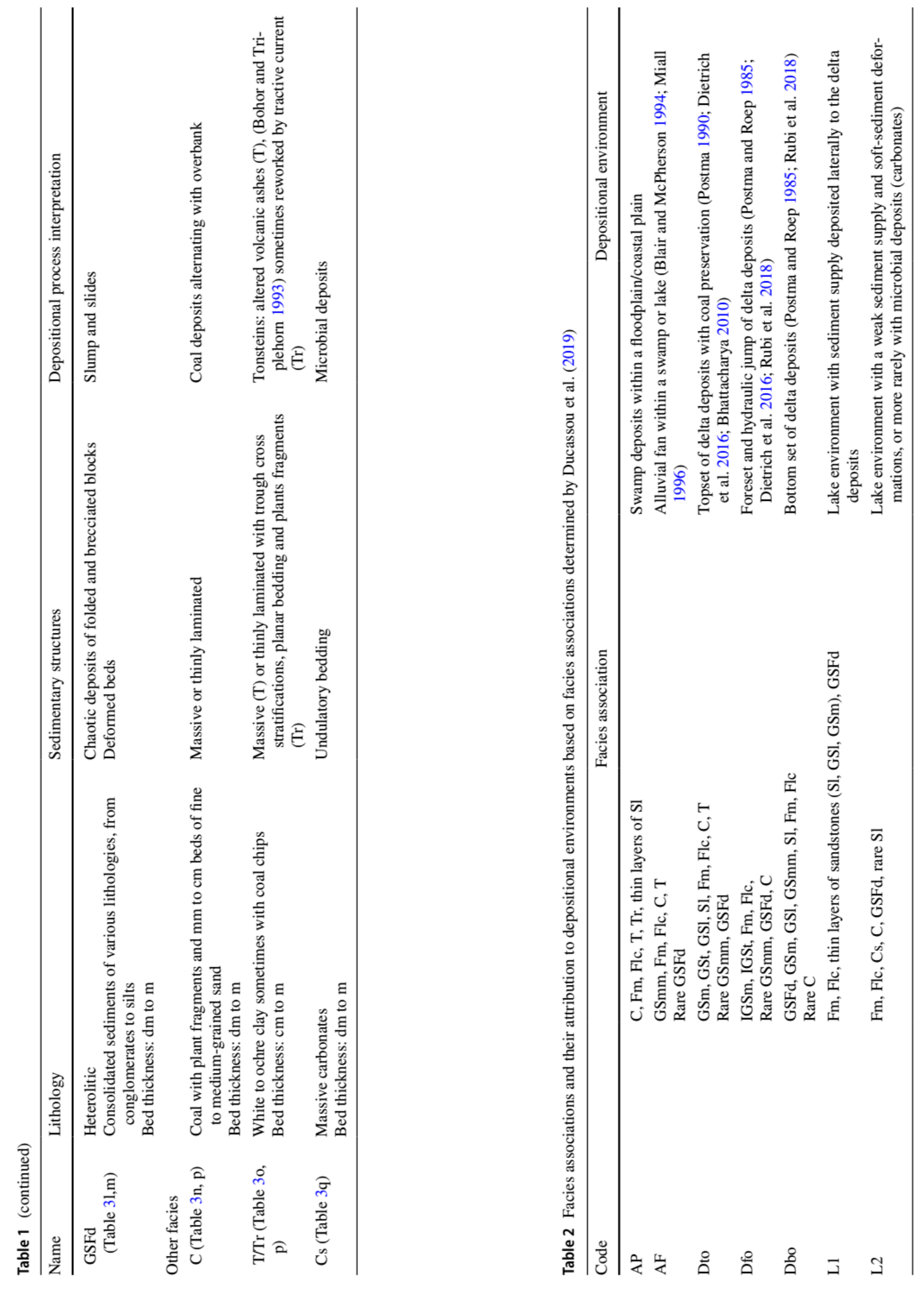
Table 3 Illustrations of the main facies described in Table 1 and in the text
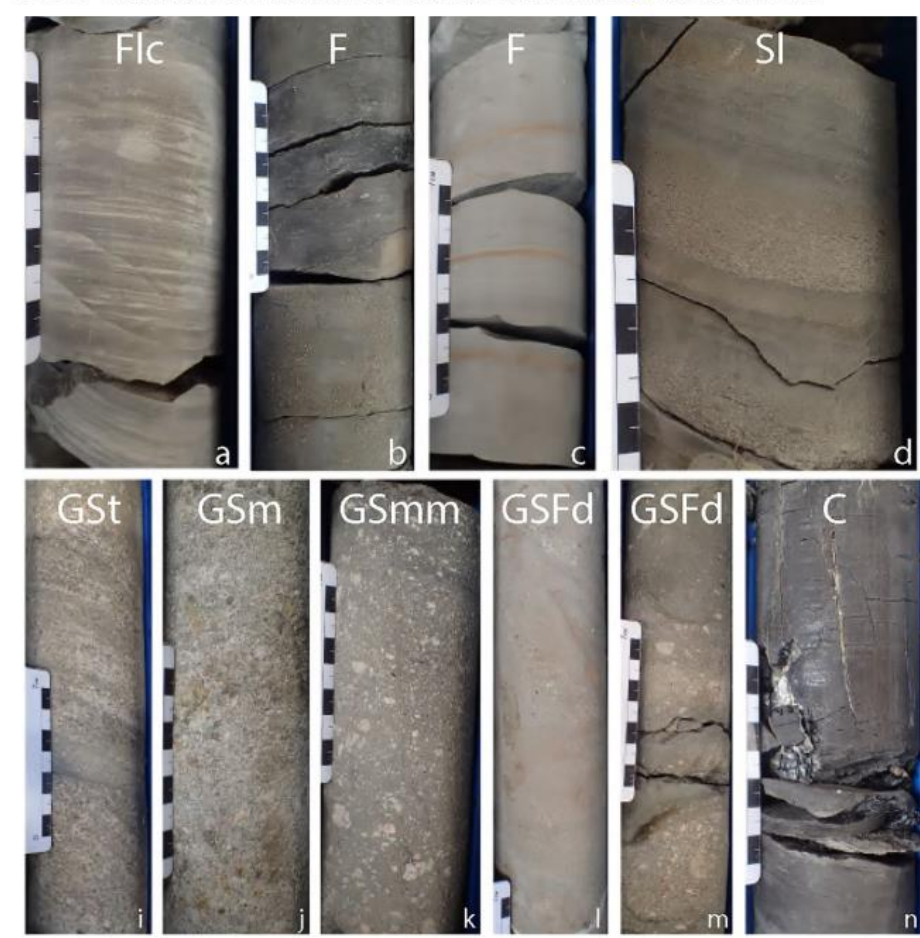
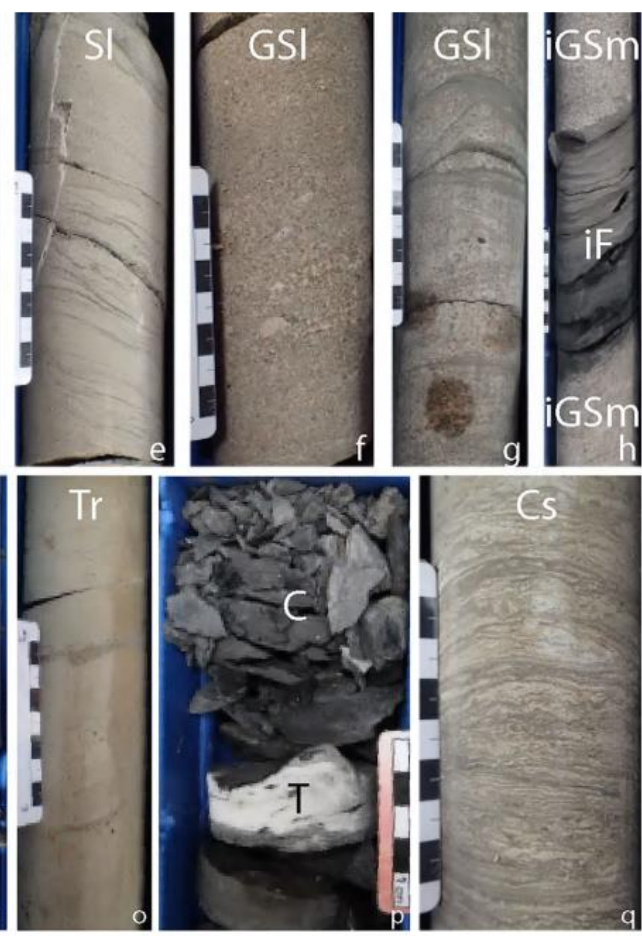

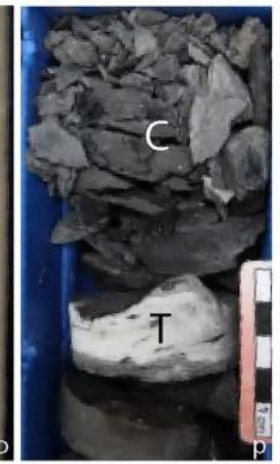

Cs

See Table 1 for the facies code

For the wells without core information, an electrofacies analysis from well-log data is necessary. Well-log data are used to calibrate electrofacies with sedimentary facies (e.g. Bourquin and Guillocheau 1996; Bourquin et al. 1998), but because only old well-log data are available in the Lucenay-lès-Aix area, a precise facies/electrofacies characterisation is not possible. The depositional environments have been identified from the well-log data on the basis of (i) the former sedimentological descriptions of the cored boreholes of the Lucenay-lès-Aix area, performed during the 1980s, and (ii) a comparison with the new descriptions of the LY-F, LY-G and LY-ZB cored boreholes.

\subsection{Sequence stratigraphy}

Bathymetry curves were built based on the depositional environment evolution established for the three cored boreholes. Each stratigraphic surface was identified through facies analysis, and used to propose a high-resolution sequence stratigraphy model, which depends, in continental environments, on the fluctuations of the stratigraphic base-level (surface below which sediments accumulate and above which erosion takes place, i.e. accommodation combined with sediment supply; e.g. Bourquin et al. (2009) and references therein). In a general way, these baselevel fluctuations are displayed as (i) periods of aggradation of the alluvial system (stratigraphic base-level rise, i.e. increasing accommodation space and/or decreasing sediment supply) and (ii) periods of stacking of the fluvial system with erosion, by pass and/or palaeosol development (stratigraphic base-level fall, i.e. decreasing accommodation space and/or increasing sediment supply). In consequence, two stratigraphic surfaces can be 
recognised: (i) the maximum flooding surfaces (MFS) that end the stratigraphic base-level rise, i.e. end of the retrogradational trend, which represents an extensive lacustrine sedimentation or alluvial plain deposits in humid depositional environments, and (ii) the end of the stratigraphic base-level fall, i.e. end of the progradational trends, that could be defined as a maximum regressive surface (MRS) in lake environments.

Stratigraphic cycles are defined from depositional environments based on facies and electrofacies analysis. In sequence stratigraphy, these cycles can be either autocyclic, resulting from internal processes, or allocyclic, resulting from local or global external factors (climate and tectonics). Although stratigraphic cycles are identified on all the available cored boreholes and on well-log data, correlations between one well and another are not possible due to the lack of reference timelines (absence of biostratigraphic data and radiometric dating); only the LY-F well is currently dated with 5 LA-ICP-MS U-Pb ages obtained from zircons and apatites collected in tonstein deposits (Ducassou et al. 2019). Additionally, the cycle definition is more precise for the wells for which core data are available. Consequently, we used a seismic analysis to constrain stratigraphic surfaces and large-scale correlations between wells.

\subsection{Well-logs and seismic data}

In a first step, the 14 seismic lines acquired in the 1980s and originally in paper format were digitised in seg-y format (i.e. dedicated to seismic softwares). Well-logs are available for 28 wells in the Lucenay-lès-Aix area (including the LY-F, LY-G and LY-ZB wells), each one with at least two and sometimes three parameters recorded: gamma-ray (GR, total natural radioactivity), neutron $(\mathrm{N})$ and gamma-gamma (GG, density), each of them measured in counts per second. In a second step, the three wells with core data were relocated on the nearest seismic lines (LY-6, LY-9 and LY-10; Fig. 2) in order (i) to propose correlations for the geological markers at the different scales (i.e. seismic, well-logs and facies association), and (ii) to reveal the large-scale geometry and evolution of the depositional environment through time and space, between the defined timelines. In a third step, the seismic profiles were integrated into a 3D GeoModeller software (Skua-GoCad software, Paradigm) for 3D visualisation and interpretation. Each profile was interpreted individually through seismic line-drawing to underlain sedimentary and structural architectures. The main seismic reflectors, discontinuities and faults were drawn on the seismic profiles. The wells with their respective well-logs were entered in the project after a depthto-time conversion using the mean velocity law based on five well data (LY-B, LY-C, LY-D, LY-E and LY-ZA).

\section{Results}




\subsection{Sedimentological descriptions and depositional environments}

Detailed sedimentary logs were drawn for the LY-G and LY-ZB cored boreholes to complete the previous descriptions of the LY-F core provided by Ducassou et al. (2019). The LY-G and LY-ZB cores display similar facies to the LY-F core (i.e. Ducassou et al. 2019); the facies of Ducassou et al. (2019) have been refined and regrouped into 13 facies (Table 1): eight conglomerate and sandstone facies, two fine-grained facies and three additional facies (coal, volcanic ashes and carbonates), each of them deposited through specific processes. The facies are illustrated on Table 3. The depositional palaeoenvironments were determined through seven facies associations (Table 2). The detailed logs were then summed up into synthetic logs (Fig. 3) to propose a vertical evolution of the sedimentary environments along a depositional profile.

\subsection{Facies associations and depositional environments}

When the cores are mostly composed of coal deposits ( $\mathrm{C}$ facies, Table 3n, p), with interbedded tonstein layers ( $\mathrm{T}$, Tr, Table 3o, p) within fine facies (Fm, Flc, Table 3a, b, c) and few sandstones (Sl, Table 3d, e), sedimentation occurs in a swamp environment in a humid restricted alluvial plain (CP facies association). The second facies association comprises the GSmm facies in metric to plurimetric beds, interpreted as mass-freezing, cohesive debris flow deposits, reworking volcanic gravels to pebbles, intercalated with some coal levels. This facies is often associated with swamp deposits (F, Flc, C, T, Table 3a, b, c, n, p), which indicates that it developed in a proximal environment, probably near the interface between air and water, and suggesting a volcaniclastic alluvial-fan delta environment (AF facies association). The environment is attributed to a delta topset (Dto association) when the dominant facies are dominated by tractive processes, marked by horizontal beds of conglomerates and sandstones (upper plan beds, trough cross stratifications, current ripples; GSl, GSt, Sl, Table 3d, e, f, i), sometimes stacked together, with some Soft-Sedimentary Deformation (SSD) occurrences (e.g. slumps, shearing, load casts, ball and pillows; GSFd facies, Table 31, m), and with some debris flow deposits (GSm, GSmm, Table 3j, k), plant remains and coal intercalations (Flc, C, Table 3a, n, p). The fourth facies association (Dfo) is composed of inclined beds of sandstones to conglomerates (IGSm, IGSt, Table 3h) alternating with inclined beds of fine-grained facies (Flc, Table 3a), marking settling periods, and with few coal levels (C, Table 3n, p). The inclined beds, gravity processes and slump occurrences (GSFd, Table 31, m) are attributed to deltaic foresets. The fifth facies association corresponds to the bottomset environment (Dbo), characterised by conglomerates and sandstones corresponding to gravity deposits (GSm, GSmm facies, Table 3j, k) or tractive currents (Sl, GSl, Table 3d, e, f, g), and by fine- 
grained facies (Flc facies, Table 3a), sometimes affected by some SSDs (GFd facies, Table 31, m). The two last facies associations record lacustrine conditions; one of them is composed of fine-grained lithologies (Flc, F, Table 3a) interbedded with some sandstone facies attributed to turbidity flow (Sl, GSm, GSl, Table 3d, e, f, g, j) with few SSDs (GSFd, Table 31, m), marking periods of detrital input into a lake environment (facies association L1). The second one (facies association L2) shows only a weak detrital supply (Sl facies reworked by wave influence and few GSFd, Table 31, m) and is characterised by the same fine facies as the L1 facies association. Some occurrences of microbial deposits (Cs facies, Table 3q) have been observed in this L2 environment, when the water column is low. With all these facies associations, the evolution of depositional environments for each cored borehole can thus be proposed (Fig. 3). 


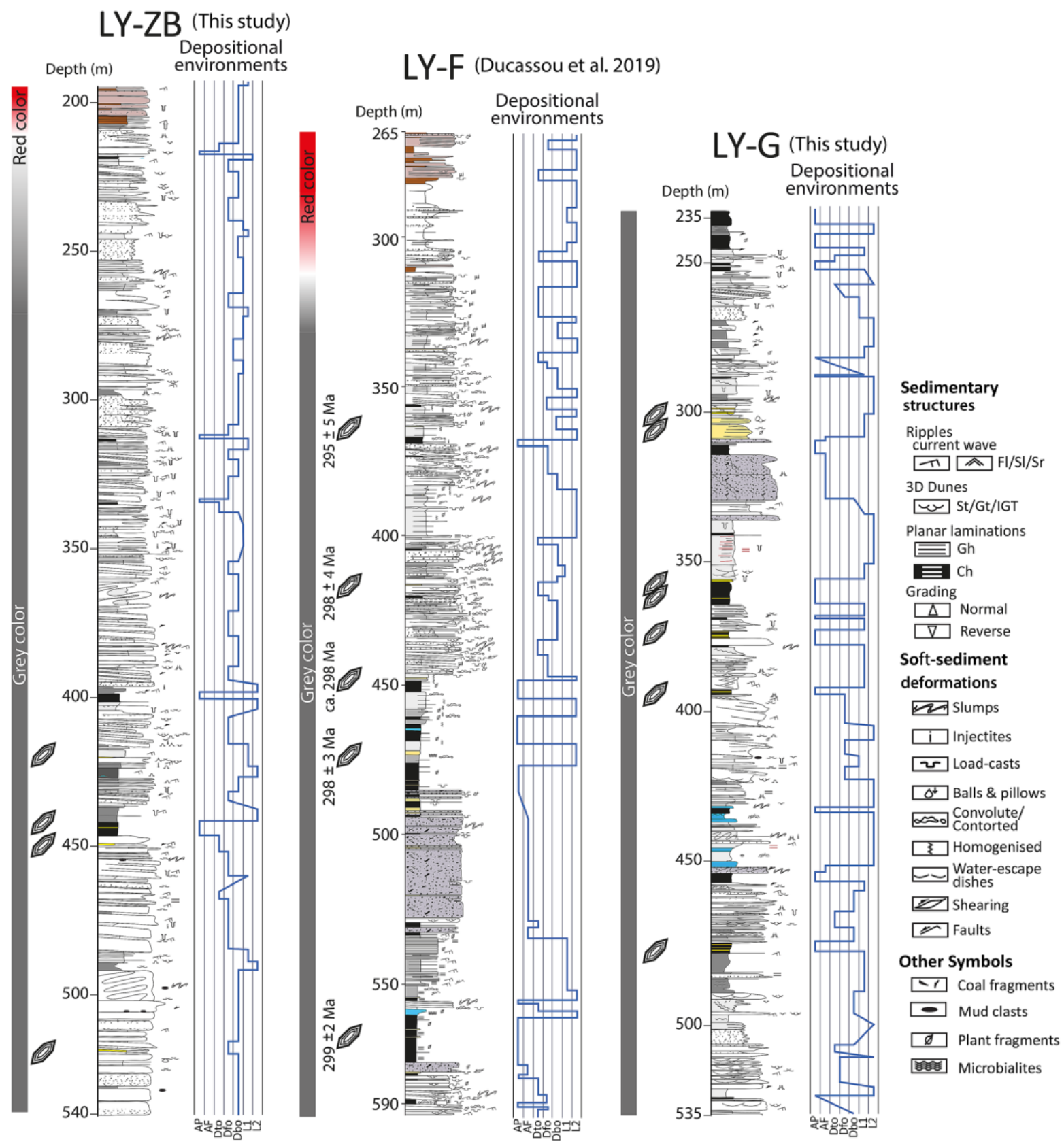

Fig. 3 Sedimentary logs of the LY-ZB (this study), LY-F ( modified from Ducassou et al. 2019), and LY-G (this study) wells, with their respective depositional environment evolution. The log caption is available in Ducassou et al. (2019)

\subsection{Well-log facies characterisation and depositional environment}

Four depositional environments have been identified from the well-log data (Fig. 4): lake, delta, volcaniclastic alluvial-fan and alluvial plain. 


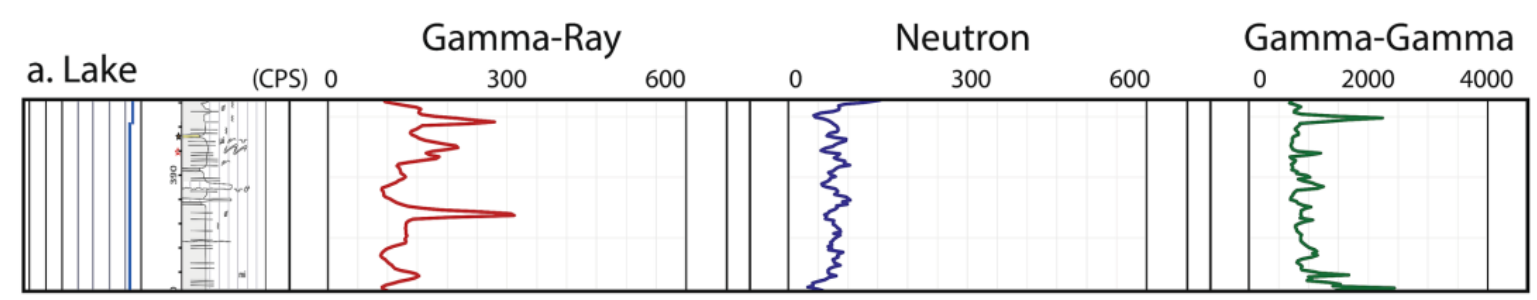

b. Delta (proximal to distal)

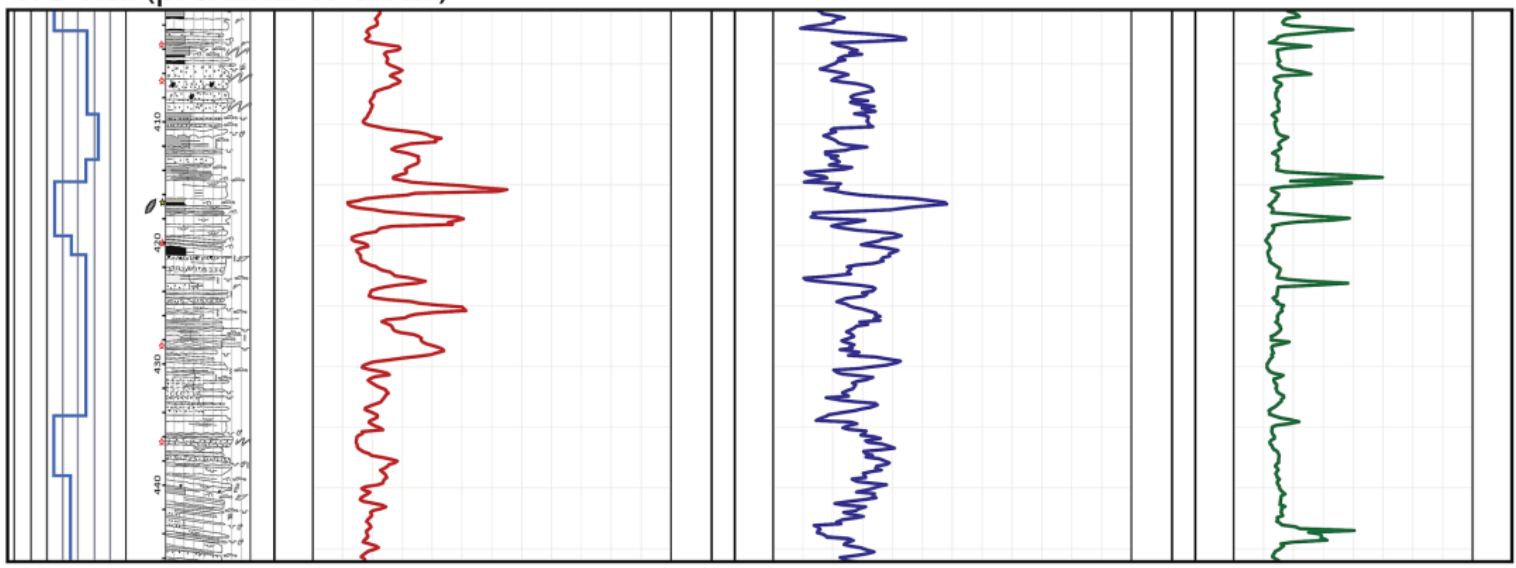

c. Volcaniclastic alluvial-fan delta

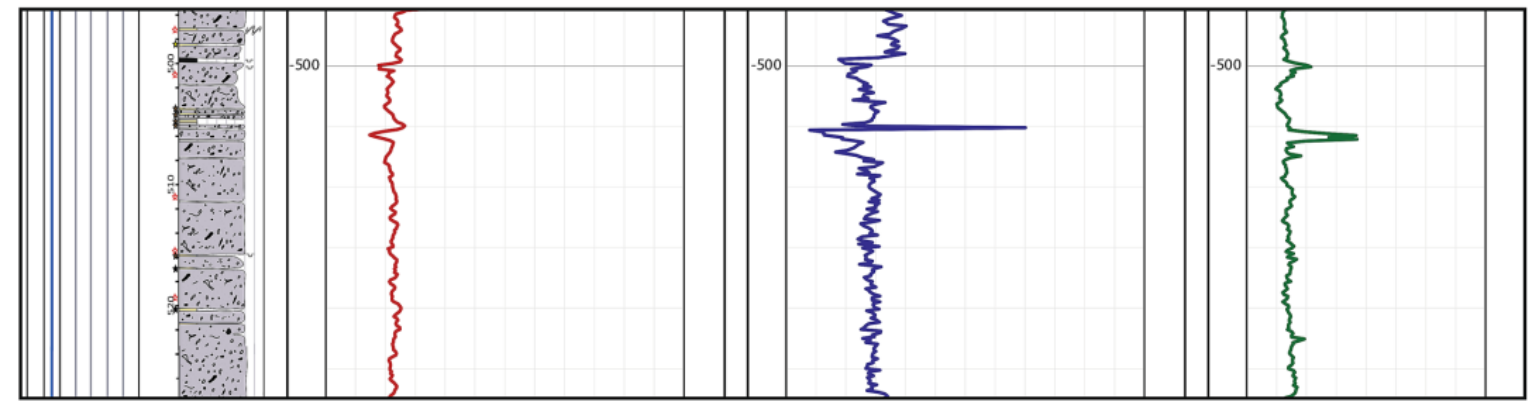

d. Coal deposits (coastal/alluvial plain)

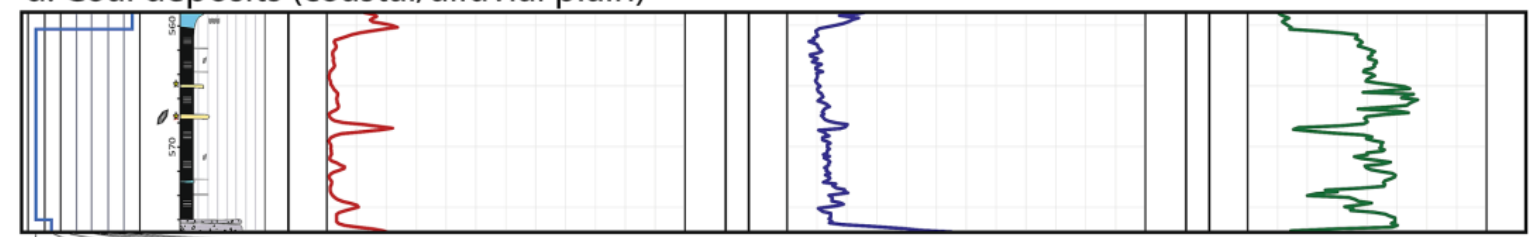

CP AF Dto Dfo Dbo L1 L2

Fig. 4 Electrofacies and sedimentary facies correspondence for the alluvial plain, the volcaniclastic alluvial-fan delta, the delta and the lake environments. The sedimentary profile is from the LY-F well (Ducassou et al. 2019)

The coal deposits usually display a low GR and N, and a high GG. Sometimes, GR is high when either coal contains uranium or is mixed with clays. This electrofacies association corresponds to the CP facies association (Table 2).

The lake environment is characterised by a fluctuating but mainly high GR, a low $\mathrm{N}$ and a low to high GG, depending on the clay content or uranium adsorbed on organic matter. This electrofacies association corresponds to L1 and L2 sedimentary facies associations (Table 2). 
The alluvial-fan delta deposits display a moderate but constant GR and N, and a low GG. This electrofacies association corresponds to the AF sedimentary facies association (Table 2).

Finally, the deltaic environments are characterised by a fluctuating GR, depending on the clay levels, and by fluctuating, but generally very high $\mathrm{N}$ and low GG. This electrofacies association corresponds to the sedimentary facies associations Dto, Dfo and Dbo (Table 2) without distinction between the proximal or distal depositional environment. To dissociate the topset, foreset and bottomset, it is necessary to pair the well-logs with the mining report descriptions in order to find indications on the sedimentary features observed when the cores were still available (e.g. stratifications, slump and slide occurrences, alternating coarse and fine granulometry, dip of the deposits). The LY-I well is shown as an example (Fig. 5) to illustrate the sedimentary facies associations inferred from the electrofacies. For this example, we distinguished three deltaic poles (proximal, medium and distal delta, Fig. 5), based on both the well-logs and the descriptions from the mining reports, that correspond to the topset, foreset and bottomset, respectively. 


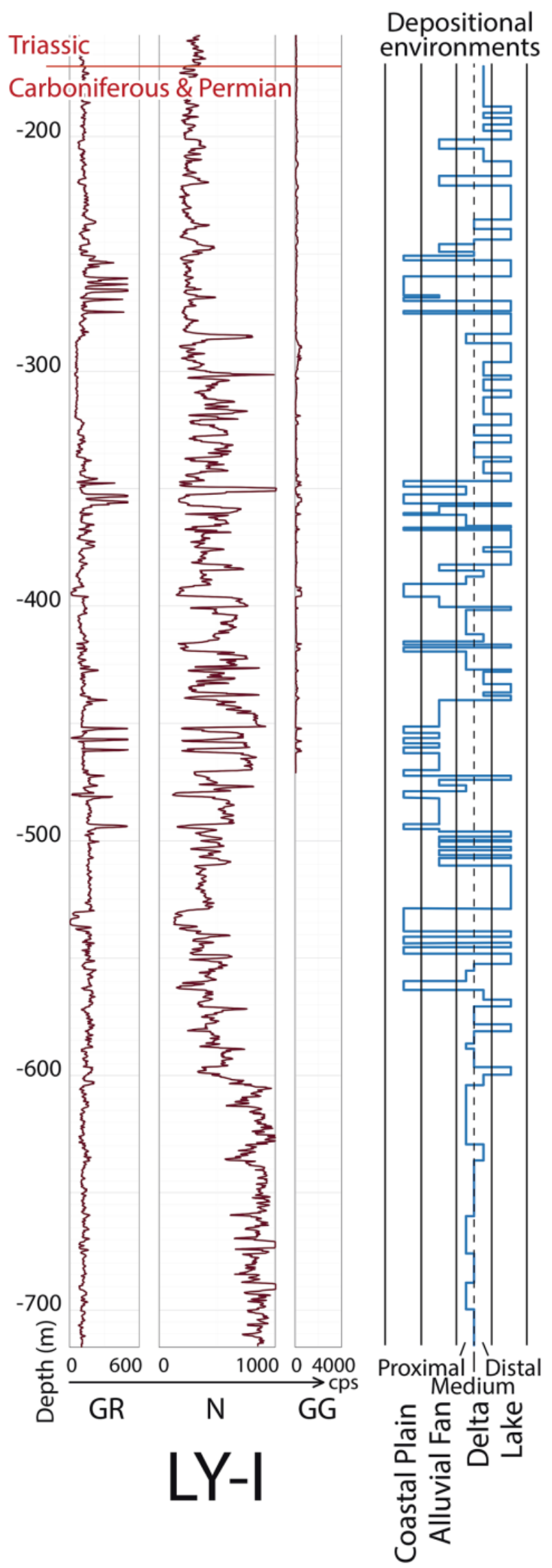

Fig. 5 Calibration of the depositional environments of the LY-I well based on well-log analyses 


\section{Sequence stratigraphy on cores and well-log and seismic correlations}

\subsection{Core, well-log and seismic interpretations}

The basin geometry and large-scale architectures are best imaged along five seismic profiles: one oriented northsouth (LY9, Fig. 6b), three oriented approximately west-east (LY6, LY8 and LY10, Fig. 6c), and one oriented SW-NE (LY5, Fig 6c). The west-east basin architecture can be seen on Figure 6c, displaying the four approximately west-east seismic lines (with north to south LY6, LY5, LY8 and LY10). The main seven seismic reflectors, identified on at least two seismic lines, are highlighted with specific colours. 


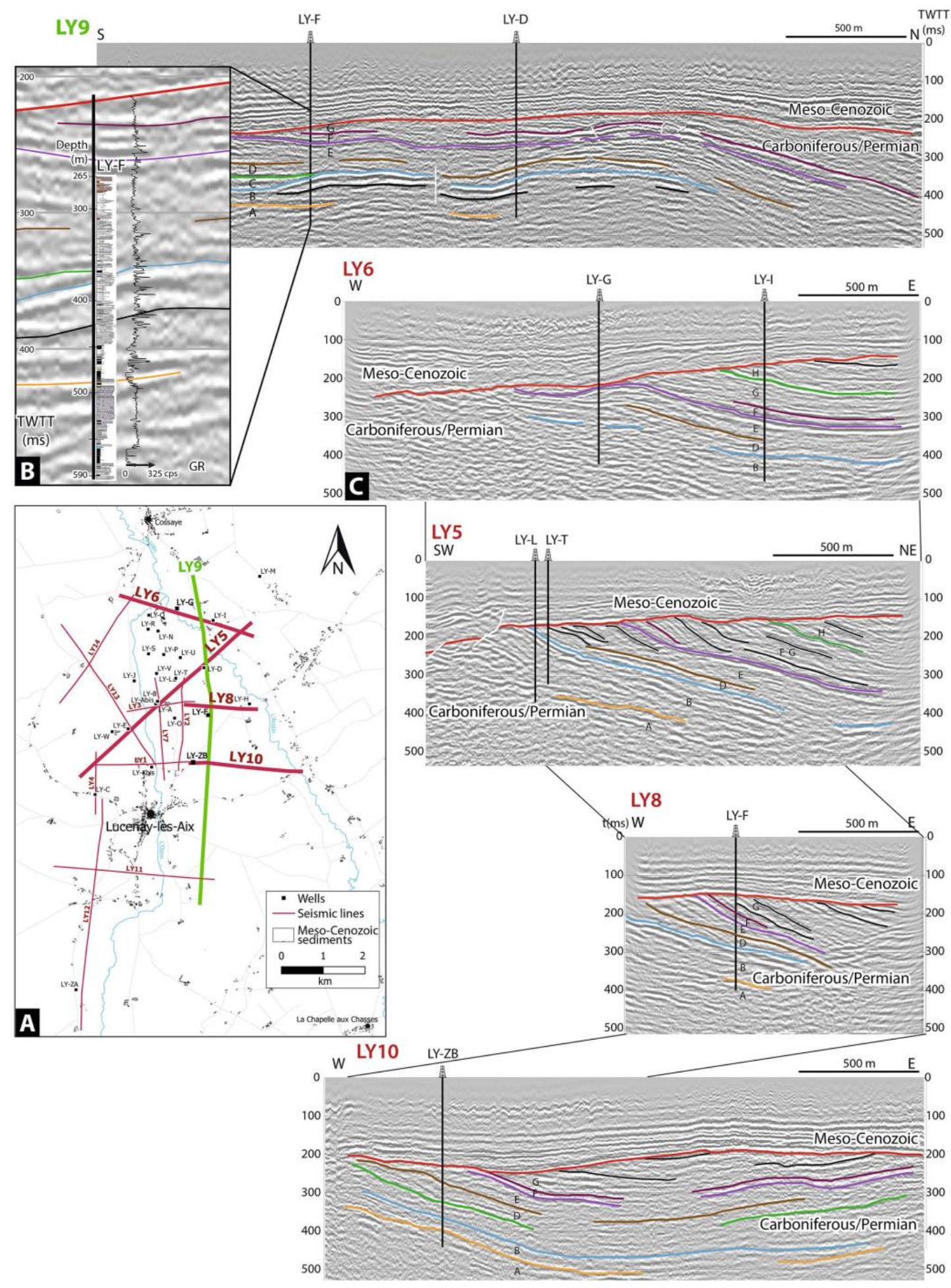

Fig. 6 A. Localisation of the seismic profiles and wells in the Lucenay-lès-Aix area. B. Calibration of the LY-F well-log along the LY-9 seismic profile. C. Interpretation of the seismic profiles LY-6, LY-5, LY-8, and LY-10

Seismic reflectors which can be seen on only one seismic line were drawn in black. The major unconformity between the Carboniferous and Permian deposits and the overlying the Meso-Cenozoic sedimentary cover is welldefined by toplap geometries below the unconformity, and is underlined in red on Figure 6. The seismic 
interpretations reveal a synclinal morphology induced by a post-depositional tectonic deformation of the sediments as represented on profile LY10 (Fig. 6c), yet the boundaries of the basin are not visible on the seismic profiles.

Therefore, we used the seismic profiles to track some time-markers between the wells. Because of the poor quality of the seismic profiles, it is difficult to associate seismic facies and sedimentary facies. However, the seismic profiles show some continuous markers (particularly above the blue marker, Fig. $6 \mathrm{~b}, \mathrm{c}$ ). Given the resolution of the seismic data, these main markers are recognised only in the central and eastern part of the Lucenay-lès-Aix area; the following discussion will therefore focus only on wells from this location. The seismic data interpretations show, from the base to the top of the Carboniferous-Permian deposits, seven main markers. Each marker was reported on the well-logs, displayed directly in the GeoModeller software, of the LY-ZB, LY-F, LY-D, LY-I and LY-G wells (Fig. 7) and of the LY-D, LY-U, LY-T and LY-L wells (Fig. 8). 


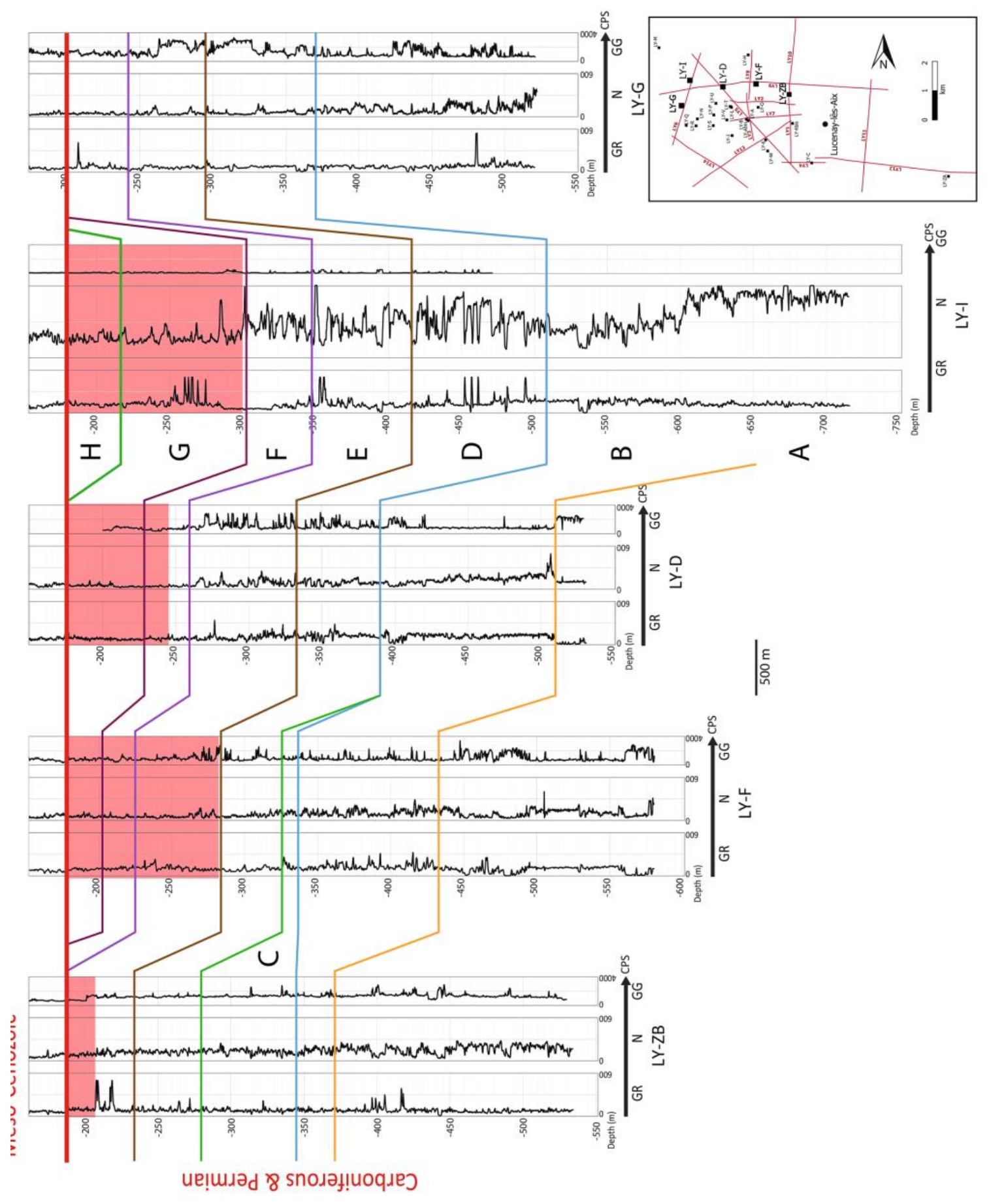

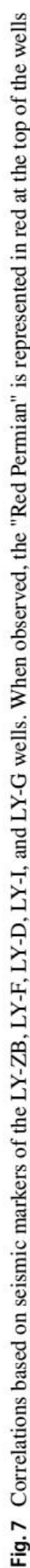




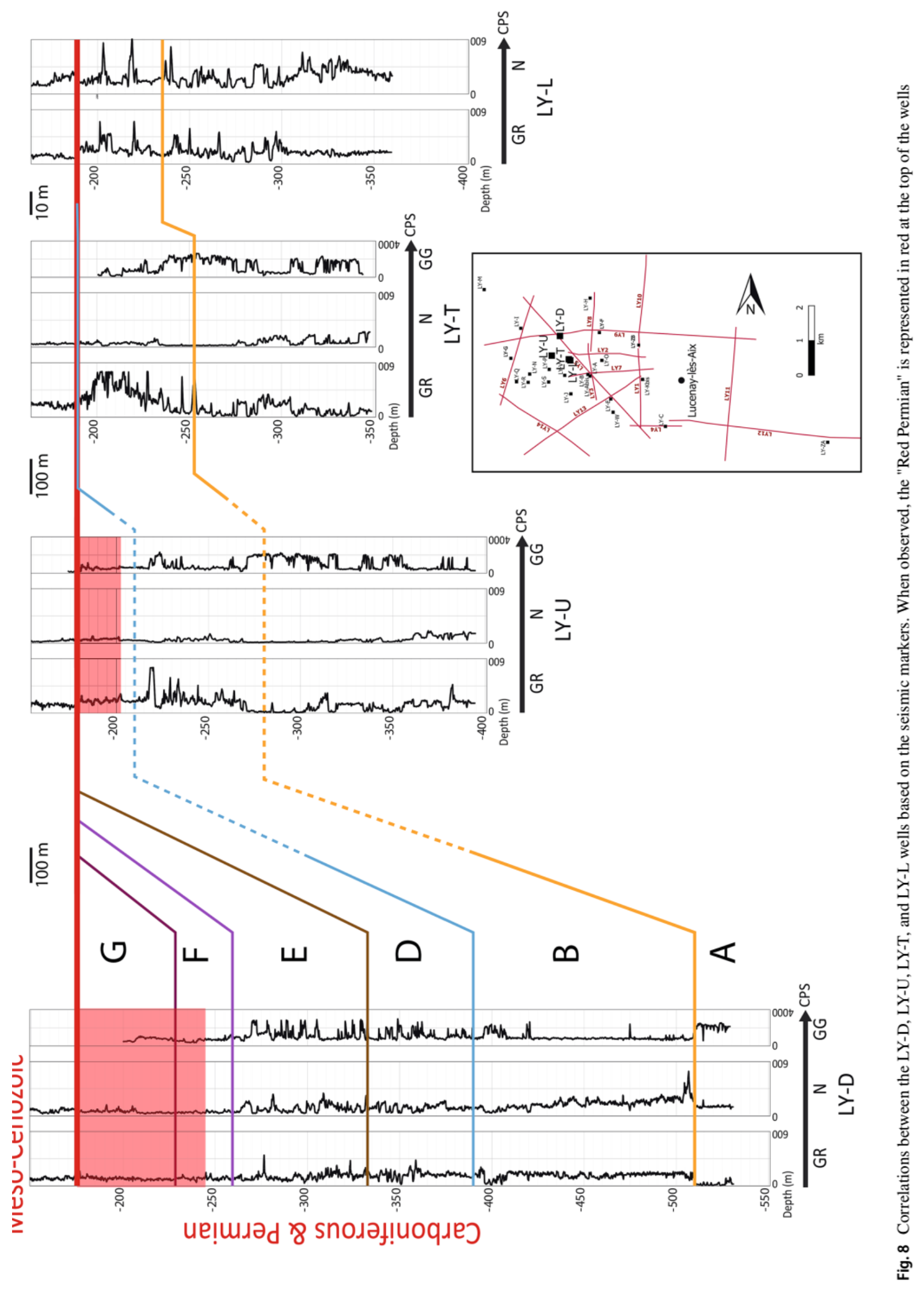


Units between these markers were named units $\mathrm{A}$ to $\mathrm{H}$ from the base to the top. As represented on the seismic profiles, these units are nearly isopach, except for unit C in the LY-ZB and LY-F wells (Fig. 6b), indicating an onlap geometry, and between the orange and the blue markers (unit B, Figs. 6b, c, 7). In a last stage, the evolution of depositional environments is obtained by combining well-log and core data for each unit identified through the seismic profiles (Fig. 9).

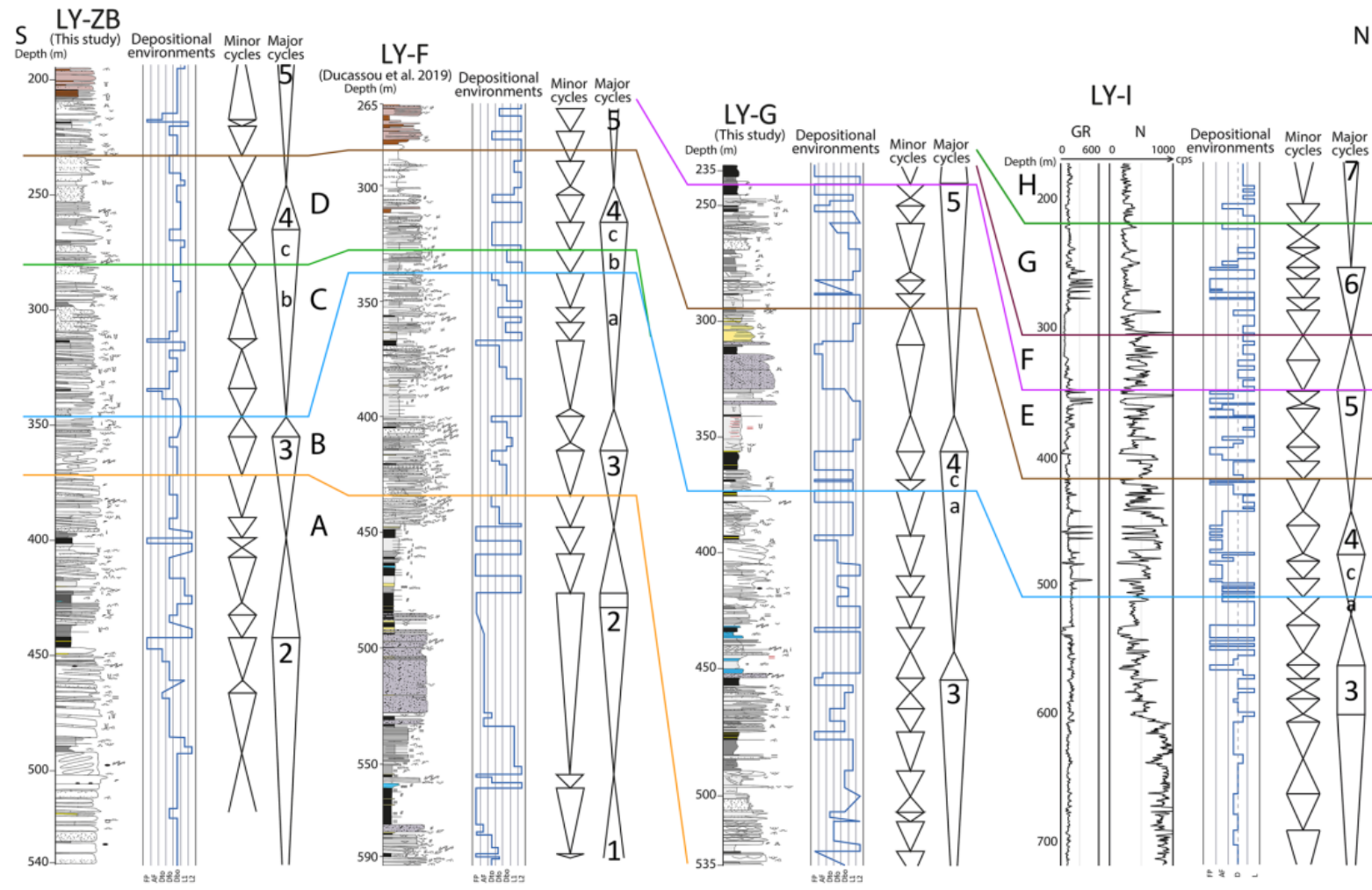

Fig. 9 Correlations between the LY-ZB, LY-F, LY-G, and LY-Y wells based on seismic interpretations and stratigraphic cycles

\subsection{Correlations of wells and 3D depositional environment evolution}

In unit A (below the orange marker), mostly proximal facies are observed. The alluvial-fan delta is dominant, and is alternating with some coal deposits and some lake facies in the LY-F well (Fig. 9), but also on the LY-L, LY-T and LY-U well-logs (Fig. 8). To the contrary, the LY-D well shows more distal facies, with mostly deltaic sequences and few coal deposits (Figs. 7, 8).

In unit B (Figs. 7 to 9), the deltaic environment dominates the succession of the LY-F, LY-G, LY-I and LY-ZB wells, and is alternating with few lacustrine facies. In the northern part of the area (LY-U, LY-T, LY-L, Figs. 6, 8) some coal deposits indicate a more proximal environment. This trend towards a more proximal pole is confirmed 
in unit C (in the LY-F and LY-ZB wells) which displays only deltaic and lacustrine deposits. Units B and C are not isopach but show a compensated geometry that may be explained by the deltaic progradations. Westward (LYP, LY-R, LY-N wells, Fig. 6a), the wells are far from the seismic profiles, and the location of the seismic markers on the well- $\log s$ is therefore uncertain. However, the $3 \mathrm{D}$ visualisation shows that these successions belong to units A and/or B (i.e. located below the blue marker) and are dominated by alluvial plain and alluvial-fan facies. This assumption is supported by the electrofacies analysis, as the LY-E and LY-J well-logs display similar facies to the LY-F well. This is confirmed by the correlations with the LY-F well and by the well-logs of the LY-E and LY-J wells which show the same facies. In unit D (Figs. 7 to 9), proximal facies are developed to the north of the area (LY-D, LY-G, LY-I and LY-U wells) and are alternating with lacustrine levels, whereas to the south, lacustrine conditions dominate and are interbedded with few deltaic facies (LY-F and LY-ZB). In unit E (Figs. 7 to 9), the lake and the delta facies are more developed to the east (LY-D, LY-F, LY-I and LY-ZB wells), whereas to the west (LY-U well) lake deposits alternate with coal. The F and G units, only observed in the LY-D, LY-F and LYI wells (Figs. 7, 9), consist of lacustrine environments northward, and mixed lacustrine to deltaic environments southward. Finally, in unit H (LY-I well, Figs 7, 9), the deltaic facies dominate. The major unconformity at the top of the succession, like in most of the Carboniferous-Permian basins in Europe (e.g. Bourquin et al. 2006; Durand, 2006; Bourquin et al. 2011), is well observed and a large part of the sediments have been eroded mainly in the western part of the Lucenay-lès-Aix area (Figs. 6c, 8). This depositional environment evolution observed at the basin scale from stratigraphic markers defined by seismic profiles (units A to $\mathrm{H}$ ) is compared with minor stratigraphic cycles observed from core and well-log data. Thus, an evolution in seven major progradationalretrogradational stratigraphic cycles is illustrated in the LY-ZB, LY-F, LY-G and LY-I wells (Fig. 9).

\subsection{Sequence stratigraphy and basin evolution}

Figure 10 illustrates the depositional environment evolution in time and space, from three wells from west to east (LY-U to LY-F) and from south to north (LY-F to LY-I). The first sequence stratigraphy cycle, denoted 1 (Fig. 10, LY-U and LY-F wells) is incomplete and only constituted by a retrogradational trend from a proximal environment (alluvial plain and alluvial-fan delta) to a lake environment. In the second cycle, located below the orange marker, (denoted 2 on Figs. 9, 10) and observed in the LY-U, LY-ZB and LY-F wells, the progradational trend is more developed than the retrogradational one. This cycle is expressed through different facies with (i) alluvial fan deposits alternating with a few coal levels in the LY-U well, (ii) mostly alluvial fan deposits in the LY-F well, and (iii) mostly bottomset deposits displaying deltaic progradations in the LY-ZB well. 


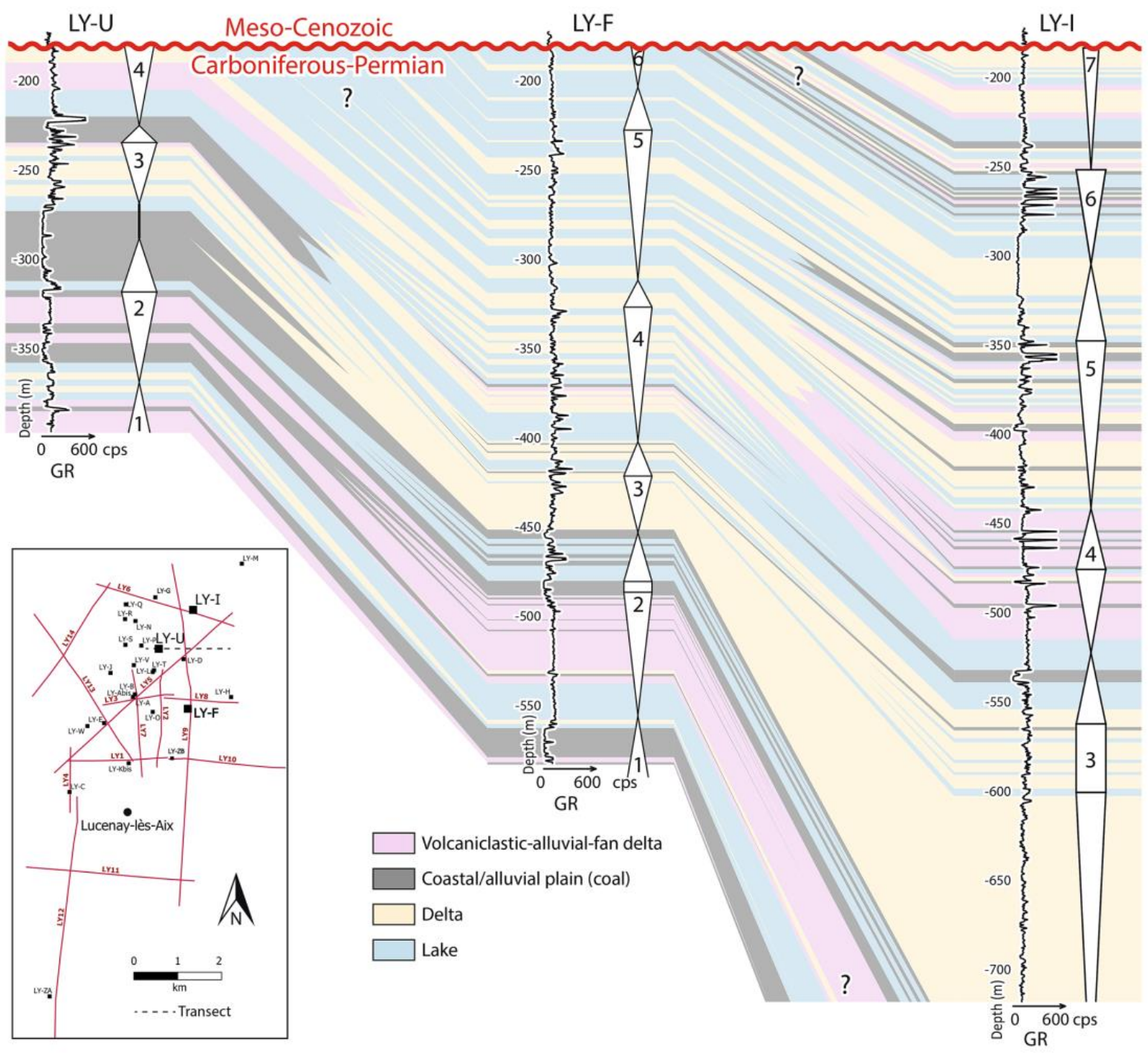

Fig. 10 Correlations between the LY-U, LY-F and LY-I wells, showing the depositional environment variations in space and time

The retrogradational trend is characterised by a greater preservation of the coal deposits in the LY-U well, occurrence of coal levels and deltaic deposits in LY-ZB well, and of lake deposits interbedded with coal in the LY-F well. Indeed, a base-level rise is necessary to preserve these coal deposits. The maximum flooding surface is characterised by the occurrence of lake deposits. In the LY-N, LY-P, LY-R and LY-T wells (located westward, Fig. 6a), this second cycle displays some coal levels alternating with alluvial-fan deposits. The third cycle, denoted 3, is recognised in five wells: LY-U, LY-F, LY-I, LY-ZB and LY-G. The well-developed progradational trend is mostly represented by deltaic deposits, up to a more or less developed coal level. The retrogradational trend is marked by thick lacustrine accumulations (up to a well-developed lacustrine level in the LY-ZB, LY-F, LY-G and LY-I wells), and by the preservation of coal in this base-level-rise context mainly in the northern part (LY-U, LYI). This third sequence should also be present in the short LY-N, LY-P and LY-R wells, as it is recognised in the LY-U well located close by, but due to the lack of seismic profiles in this area this cannot be confirmed. The fourth 
cycle, denoted 4 (Figs. 9, 10), shows a well-developed progradational trend from lake to delta or alluvial plain environments in the LY-ZB, LY-F, LY-G and LY-I wells, and the occurrence of alluvial-fan deposits in the northern area, i.e. LY-U and LY-I wells. This progradational trend can be divided into three parts $(4 \mathrm{a}, 4 \mathrm{~b}$ and $4 \mathrm{c}$, Fig. 9), separated by the blue and green seismic markers. These three parts are well-preserved in the LY-F well, with the $4 \mathrm{a}$ part located in unit $\mathrm{B}$, the $4 \mathrm{~b}$ part in unit C, and the $4 \mathrm{c}$ part in unit D. In the LY-ZB well, as unit B is tightened compared to the LY-F well, the lower part of the progradational trend (4a; Fig. 9) is absent, stacked with the top of cycle 3 , while the $4 \mathrm{~b}$ part is well-developed. This geometry could reflect a compensated architecture of delta deposits (Figs. 6, 8, 9, 10), with the presence of two and half minor cycles preserved in the LY-ZB well, compared to only one half in the LY-F well (Fig. 9). Similarly, part 4a is well-developed in the LY-F and LY-G wells, and part $4 \mathrm{~b}$ is missing in the LY-G and LY-I wells, due to the stacking of the blue and green markers (Fig. 9). Because of the Permian-Mesozoic unconformity, the retrogradational trend of the fourth cycle and the following cycles (denoted 5 to 7, Fig. 10) are not present in the LY-U well, nor in the short wells from the same area (i.e. LY-N, LY-P, LY-R and LY-T wells, Figs. 6, 7, 8). The retrogradational trend of cycle 4 is short in each well, representing only one minor cycle (on core and well-log data), with a termination in a lake environment (Fig. 9). The fifth cycle is characterised by a large progradational trend as shown in the LY-G and LY-I wells, up to the top of the E unit (Fig. 9). Toward the north, this trend is materialised by lake, delta and alluvial plain (coal) deposits whereas in the LY-F and LY-ZB wells, to the south, the facies are more distal, mostly with lacustrine or bottomset deposits. The retrogradational trend is displayed only in the LY-I and LY-F wells (Figs. 9, 10), whereas the deltaic deposits observed in the LY-I well are replaced by lacustrine deposits in the LY-F well (Figs. 9, 10). The maximum flooding surface between cycles 5 and 6 is located at the top of the F unit (Figs. 9, 10). The progradational trend of the sixth cycle is observed in the northern part (i.e. LY-I well) whereas more south, i.e. in the LY-F well, this trend is topped by the Permian-Triassic unconformity (Fig. 10). Last, the seventh cycle (units G and H) is only represented in the LY-I well, showing the progradation of the deltaic deposits. Despite the fact that the LY-M well is far away from the seismic profiles and thus cannot be correlated with the other wells (Fig 6a), it presents distal facies (i.e. deltaic and lacustrine, without coal occurrence) indicating that proximal deposits are not extending toward the east.

To sum up, because of the tectonic structure of the basin, units E, F, G and $\mathrm{H}$ are not present in the wells located in the western part of the studied area (Fig. 6b). The seven stratigraphic cycles show a general retrogradational trend with increasing lacustrine deposits in sequences 1 to 6 , with well-extended lacustrine deposits between the MFS of sequences 5 and 6, suggesting an extended lake at the top of the succession (Fig. 10). The correlations of 
seismic and well data therefore suggest that the synclinal morphology observed from the seismic lines is a postdepositional structure and that the present-day boundaries of the basin are not representative of the boundaries at the time of the sedimentary filling.

\section{Discussion}

\subsection{Refining the depositional environments of the Decize-La Machine basin}

Three type of depositional environments were previously described in the first studies of the Decize-La Machine basin: palustrine, fluvial and lacustrine (Donsimoni 1990). Our study shows that these depositional environments need to be reassessed in the light of the new sedimentological descriptions and available methods. As stated in Ducassou et al. (2019), the facies and facies association descriptions have shown that the sediments were mainly deposited in an aquatic environment with deltaic influences. Only the coal-bearing sequences and alluvial-fan deposits reflect a subaerial environment. The main argument in favour of subaquatic deposits is the presence of large-scale turbidite deposits and soft sedimentary deformations in the sandy to conglomerate facies, such as slumps, convolutes, injectites and load features, characteristic of sediments deposited under a certain water column. Indeed, such deformations result either of a high sediment supply or from gravitational instabilities along a slope, as envisaged in delta foresets (e.g. Pisarska-Jamrozy and Weckwerth 2013). These kinds of depositional environments were already mentioned for the Aumance Basin, located westward to the Decize-La Machine Basin, were deltaic progradations are shown, with distributaries coming from the west and south-east (Mathis and Brulhet 1990).

Within this sedimentary context, sequence stratigraphy correlations from only well-log and core data are tricky to realise in both continental successions and post-depositional deformed basins. Moreover, in a deltaic palaeoenvironmental context with progradation of deltaic systems, the minor cycles (auto or allocyclic, Fig. 7) are not stacked vertically but laterally (e.g. recent deltaic system of Corinth, Rohais et al. 2007; Rubi et al. 2018). In consequence, a combined analysis including subsurface data (core and well-logs) and seismic profiles is required to perform basin-scale sequence stratigraphy correlations. The major cycles defined in previous work (Ducassou et al. 2019) only reflect the 1D evolution without integrating the entire basin evolution. In the present study, the stratigraphic cycles initially defined by Ducassou et al. (2019) for the LY-F well (Fig. 2b) have therefore been reassessed considering both the available well-log at the top of the well (in the part without core data) and the pattern of progradational-retrogradational trends obtained from the facies analysis of the other cored wells (Fig. 
10). In the Lucenay area, most of the minor sequences observed are not complete, and display only progradational trends, and only a minority of sequences show both a progradational and a retrogradational trend (Fig. 9). This study highlights the progradational feature of deltaic systems in the Lucenay-lès-Aix area, with delta compensation beneath the green marker (Fig. 9).

Figure 11 shows palaeogeographic maps displaying the depositional environment evolution through time, between the defined timeline seismic markers which can be correlated at the scale of the studied area. These palaeogeographic maps were built by selecting the most representative environments in each unit. The alluvialfan delta deposits are either under the lake water (when the GSmm facies presents some slump and slide and injectite occurrences, Fig 11a, c), or above the lake level, in the alluvial plain, where it is associated with the coal deposits (Fig. 11b). This palaeogeographic evolution shows that the depositional environments are more and more dominated by the lake and the delta through time. The direction of progradation of the deltaic systems is poorly known, but the facies distribution seems to indicate a sediment supply coming from the south-west (Fig. 11a-e) and from the north (Fig. 11c, d, e), whereas the alluvial fan delta would come from the north-west (Fig. 11a, b, c). Moreover, Ducassou et al. (2019) suggested that there is one main episode of volcaniclastic alluvial-fan deposits; our study, through the correlations between wells based on seismic data, shows that there are rather two episodes (Figs. 9, 10, cycles 1-2 and cycle 4) although it is uncertain if they can be directly attributed to several contemporaneous volcanic events or be linked to previous volcanic material reworking (e.g. Ducassou et al. 2019 for discussion). From the ages obtained for the LY-F well (Fig. 2b, 11, Ducassou et al. 2019), we consider that the succession of the Lucenay-lès-Aix area between cycles 1 and 4 correspond to the boundary between the Carboniferous and Permian, with a late Gzhelian to early Asselian age, and could therefore be correlated with the lower Autunian (Igornay Fm or Muse Fm) defined in the Autun Basin (299.9 \pm 0.38 Ma to 298.05 \pm 0.19 Ma; Pellenard et al. 2017). 

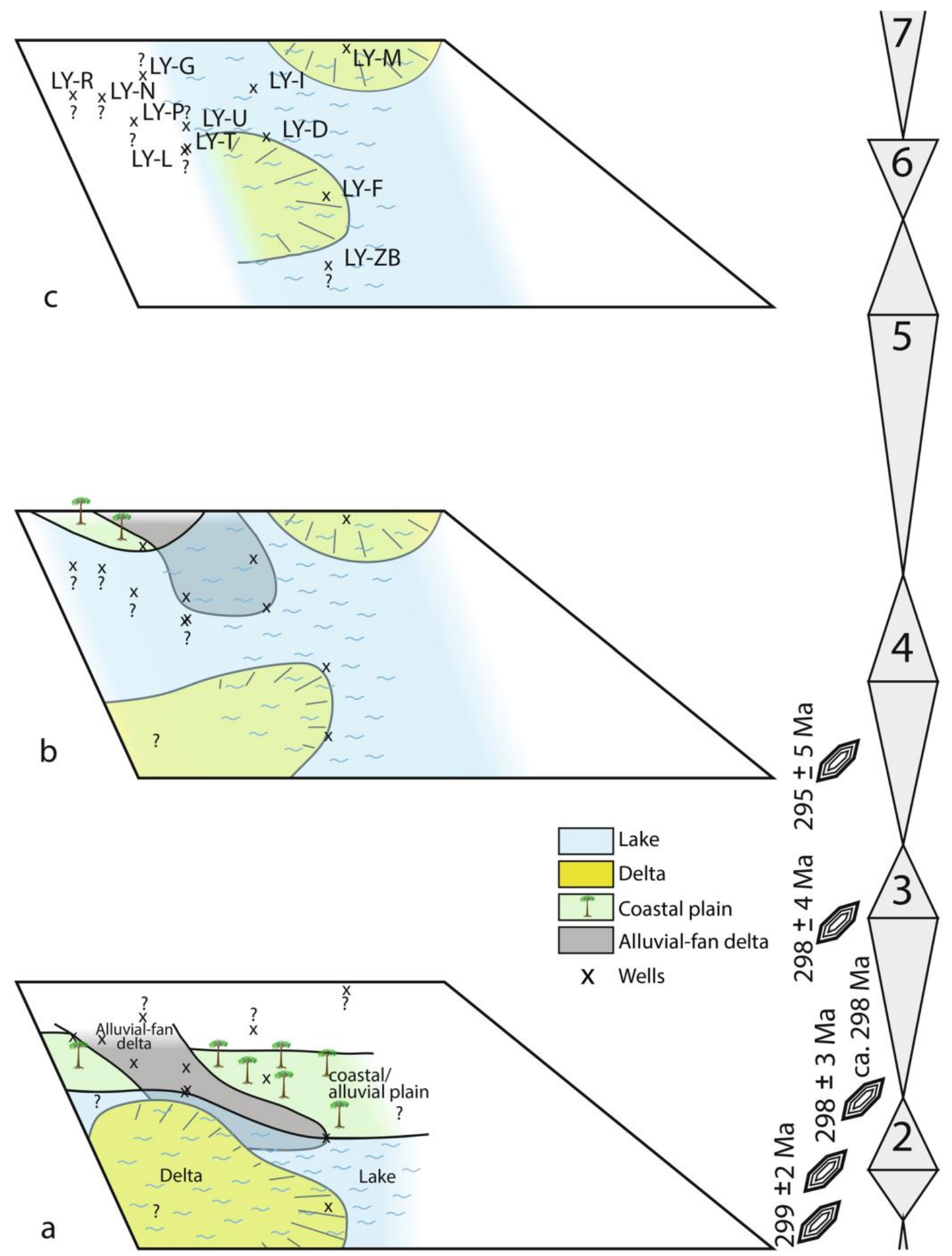

Fig. 11 Palaeogeographic maps showing the depositional environment evolution through time at the scale of the basin

In some basins of Western Europe, the terms Grey and Red Permian are used as stratigraphic units to date the sedimentary succession, as it is the case for the Decize-La Machine Basin (Donsimoni 1990). This nomenclature 
implies that the boundary between the grey and red deposits is synchronous at the scale of the basin and constitutes a limit between two distinct depositional environments: one dominated by a reduced grey facies and the other allowing the deposition and preservation of more oxidised red facies (e.g. Ducassou et al. 2019, LY-F well). The use of the difference in colour as a timeline should be possible only if, by definition, the change from the grey to red colour is synchronous within and between all the relevant basins. However, by working on several wells in the Lucenay-lès-Aix area (Figs. 7, 8, 9), it is clear that the boundary between the grey and red facies cannot be correlated between the wells using the sequence stratigraphy proposed and is therefore diachronous. This highlights that (i) the previously described Grey and Red Autunian units are not representative of a real stratigraphic unit that can be applied to continental successions, and (ii) the red colour is most probably the effect of differential diagenesis. In the study of Ducassou et al. (2019), the change from grey to red colour was attributed to a change in the depositional environment, from a lacustrine to a playa-lake environment (Fig. 2). By refining the facies description, and integrating this study at the basin scale, we actually do not observe any drastic change in the depositional environments (Fig. 10). The red deposits present similar facies to the grey deposits, aside the colour, and are therefore attributed to lacustrine to deltaic deposits, later affected by diagenesis. Thus, the depositional profile of the LY-F core was modified from Ducassou et al. (2019) in Figure 7, and the depositional profile of the red part of the LY-ZB core was drawn accordingly. Moreover, it has been shown in Germany that the grey (coal) and red deposits ("wet red beds") were deposited synchronously, for example between the Thuringian Forest and Saale basins, demonstrating that the red Permian is not necessary younger that the grey Permian (Schneider and Scholze 2018).

\subsection{The Decize-La Machine Basin: part of a larger Carboniferous-Permian basin?}

The Lucenay-les-Aix area is described as a hemi-graben basin bounded by a major synsedimentary fault, oriented $\sim \mathrm{N}-\mathrm{S}$ and located to the west of the basin, which controls, with another minor syn-sedimentary fault at the centre of the area, the type and thickness of the sedimentation (e.g. phytogenic sedimentation, Donsimoni 1990). However, by interpreting the seismic profiles, no fault has been evidenced, except one on the LY-11 profile, oriented $\sim \mathrm{N}-\mathrm{S}$, but affecting both the Carboniferous-Permian succession and the Meso-Cenozoic ones, and therefore considered as a post-depositional fault. Our new correlations indicate that the apparent difference in the thickness of the coal deposits observed between the eastern and western part of the area is in reality only due to the post-sedimentation deformation affecting the succession: the well-developed coal deposits preserved in the western part of the Lucenay-lès-Aix area are in fact correlated with the base of the succession of the eastern part (i.e. unit A, Figs. 6, 10), which were not systematically cored (e.g. LY-I well, Fig. 10). 
Based on these new data, the initially inferred hemi-graben structure is not demonstrated. The structuration of the basin (i.e. synclinal morphology, Fig. 6) is given by a post-depositional deformation that took place either during Permian (post-lower Permian, e.g. Saalian or Altmark phases, Copestake et al. 2003), or after the Permian but before the Triassic (Bourquin et al. 2011). South of the Paris Basin, close to our study area, large-sized Carboniferous-Permian basins (Contres, Brécy and Arpheuilles basins) have also been detected under the MesoCenozoic sedimentary cover since the 1980s (Debéglia 1980; Lebreton 1990; Mascle 1990; Perrodon and Zabek 1990; Delmas et al. 2002), and were recently re-evaluated through seismic data interpretations (Beccaletto et al. 2015); the latter demonstrate that these subsurface basins experienced several deformation events both during and after their sedimentation. For instance, this is the case for the Brécy Basin, where the edges were uplifted during Permian (Beccaletto et al. 2015), giving the basin a synclinal morphology and triggering the subsequent erosion of the edges, followed by the deposition of the Triassic succession.

Beccaletto et al. (2015) also show that the Aumance Basin (located $30 \mathrm{~km}$ to the west of our study area) could be an outcropping termination of these large subsurface basins. Given the very close proximity between the DecizeLa Machine Basin and the Aumance Basin, it is highly possible that the Decize-La Machine Basin was also formed in the continuation of these large basins. Besides the location of the Lucenay-lès-Aix area south to the outcropping Decize-La Machine Basin, some other deep cored wells have indicated that the Carboniferous and Permian deposits also extend north, west and east to the Decize-La Machine area. Moreover, seismic data for the Lucenaylès-Aix area (this study) do not show the boundaries of the basin (such as a major fault between the magmatic basement and the sedimentary succession, or an onlap over the basement), except perhaps in the eastern part of the area, as suggested by the synclinal morphology observed on the LY-10 profile (Fig. 6). Finally, the study of the depositional environments has highlighted that the more proximal deposits are located in the western part of the area $(\mathrm{CP}$ and $\mathrm{AF})$, and that the lacustrine and deltaic deposits are mostly in the eastern part, indicating that the basin opens towards the east (Fig. 11). For instance, the LY-M well, located in the easternmost part of the study area, does not display any coal deposits.

If the connection with the Aumance Basin to the west is probable, it would be interesting to look for a possible connection with another Carboniferous to Permian basin toward the east, such as the Autun and Blanzy-Le Creusot basins located respectively only $60 \mathrm{~km}$ and $40 \mathrm{~km}$ east of the study area (Fig. 12), and displaying distal lacustrine facies (black shales). If the connection between several sub-basins or the existence of one large basin south of the Paris Basin during the Carboniferous and Permian time is proven, this would have significant geodynamic 
implications, in terms of tectonics (amount of eroded rocks), and perhaps climate (atmospheric $\mathrm{CO}_{2}$ storage in organic matter).

\section{Conclusion}

The Decize-La Machine Basin, particularly the Lucenay-lès-Aix area, displays sedimentary successions attributed to alluvial plain, lacustrine and deltaic environments without evidence of fluvial environments. This basin was structured after the sedimentation, as shown by its W-E synclinal morphology. This structuration, and the fact that continental deposits display a strong lateral variability in terms of facies, means that direct correlations cannot be made between the available wells based only on the facies descriptions. Thus, a multidisciplinary approach has been used in this study to make intrabasinal correlations: the well-log data from 12 wells were paired with three detailed sedimentary logs and facies descriptions to determine the palaeoenvironmental evolution through time and space, and to define a reliable sequence stratigraphical scheme across the Lucenay-lès-Aix area. By visualising the data on a 3D seismic viewer (i.e. seismic profile and well-log data), some major markers (considered as timelines) have been reported on the logs and well-logs to make correlations, confirmed by the use of sequence stratigraphy. These results show that (i) the Lucenay-lès-Aix area is comparable to the Aumance Basin, with coal deposits and development of delta into a lacustrine system, (ii) the environments become more lacustrine through time, with the disappearance of the more proximal facies (coal and alluvial-fan delta deposits), and (iii) the basin seems to open towards the east. Finally, the current boundaries of the Decize-La Machine Basin are only erosive, suggesting that this basin could be part of a larger one, encompassing the Aumance basin and perhaps even the more eastern Autun and Blanzy-Le Creusot basins. Occurrences of such wide basins would lead us to greatly reevaluate the size and thickness of Carboniferous-Permian basins and related sedimentation in France and Western Europe. A next step would be to deconvolute the sedimentary record, to distinguish the role of tectonic and climatic controlling parameters - i.e. to discuss the respective impact of erosional processes at the end of the Variscan orogeny and in the end-Palaeozoic climate dynamic. 


\section{References}

Ballèvre M, Bosse V, Ducassou C, Pitra P (2009) Palaeozoic history of the Armorican Massif: models for the tectonic evolution of the suture zones. Comptes Rendus Géosciences 341:174-201

Ballevre M, Bosse V, Dabard MP, Ducassou C, Fourcade S, Paquette JL, Peucat JJ, Pitra P. (2013) Histoire géologique du Massif armoricain : actualité de la recherche. Bulletin de la Société Géologique et Minéralogique de la Bretagne, Société géologique et minéralogique de Bretagne 10:5-96

Ballèvre M, Catalán JRM, López-Carmona A, Pitra P, Abati J, Fernández R.D, Ducassou C et al. (2014) Correlation of the nappe stack in the Ibero-Armorican arc across the Bay of Biscay: a joint French-Spanish project. Geological Society, London, Special Publications 405:77-113

Beccaletto L, Capar L, Serrano O, Marc S (2015) Structural evolution and sedimentary record of the StephanoPermian basins occurring beneath the Mesozoic sedimentary cover in the southwestern Paris basin (France). Bulletin de la Société Géologique de France 186:429-450

Becq-Giraudon JF, Montenat C, Van Den Driessche J (1996) Hercynian high-altitude phenomena in the French Massif Central: tectonic implications. Palaeogeography, Palaeoclimatology, Palaeoecology 122: 227-241

Berner RA (2006) Geological nitrogen cycle and atmospheric N2 over Phanerozoic time. Geology 34:413-415

Bhattacharya JP (2010) Delta. In: James NP and Dalrymple RW Facies Models 4, GEOtext pp 233-264

Bishop JW, Montañez IP, Osleger DA (2010) Dynamic Carboniferous climate change, Arrow Canyon, Nevada. Geosphere 6:1-34

Blair TC and McPherson JG (1994) Alluvial fans and their natural distinction from rivers based on morphology, hydraulic processes, sedimentary processes, and facies assemblages. Journal of sedimentary research 64:450-489 Bohor BF and Triplehorn DM (1993) Tonsteins: altered volcanic ash layers in coal-bearing sequences. Geological Society of America Special Paper 285

Bouma AH (1962) Sedimentology of some flysch deposits. A graphic approach to facies interpretation. Elsevier Publishing Company, University of California

Bourquin S, Guillocheau F (1996) Keuper stratigraphic cycles in the Paris Basin and comparison with cycles in other Peritethyan basins (German Basin and Bresse-Jura Basin). Sedimentary geology 105:159-182 
Bourquin S, Rigollet C, Bourges P (1998) High-resolution sequence stratigraphy of an alluvial fan-fan delta environment: stratigraphic and geodynamic implications-An example from the Keuper Chaunoy Sandstones, Paris Basin. Sedimentary Geology 121:207-237

Bourquin S, Peron S, Durand M (2006) Lower Triassic sequence stratigraphy of the western part of the Germanic Basin (west of Black Forest): fluvial system evolution through time and space. Sedimentary Geology, 186:187211.

Bourquin S, Guillocheau F, Péron S (2009) Braided rivers within an arid alluvial plain (example from the Lower Triassic, western German Basin): recognition criteria and expression of stratigraphic cycles. Sedimentology $56: 2235-2264$

Bourquin S, Bercovici A, López-Gómez J, Diez JB, Broutin J, Ronchi A. et al. (2011) The Permian-Triassic transition and the onset of Mesozoic sedimentation at the northwestern peri-Tethyan domain scale: palaeogeographic maps and geodynamic implications. Palaeogeography, Palaeoclimatology, Palaeoecology 299:265-280

Breda A, Mellere D, and Massari F (2007) Facies and processes in a Gilbert-delta-filled incised valley (Pliocene of Ventimiglia, NW Italy). Sedimentary geology 200:31-55

Broutin J, Doubinger J, Langiaux J, Primey D (1986) Conséquences de la coexistence de flores à caractères stéphaniens et autuniens dans les bassins limniques d'Europe occidentale. Mémoires de la Société géologique de France 149:15-25

Broutin J, Doubinger J, Farjanel G, Freytet P, Kerp H (1990) Le renouvellement des flores au passage Carbonifère Permien: approches stratigraphique, biologique, sédimentologique. Comptes rendus de l'Académie des sciences. Série 2, Mécanique, Physique, Chimie, Sciences de l'univers, Sciences de la Terre 311: 1563-1569

Broutin J, Châteauneuf JJ, Galtier J, Ronchi A (1999) L'Autunien d'Autun reste-t-il une référence pour les dépôts continentaux du Permien inférieur d'Europe? Apport des données paléobotaniques. Géologie de la France 2:17-31

Bruguier O, Becq-Giraudon JF, Champenois M, Deloule E, Ludden J, Mangin D (2003) Application of in situ zircon geochronology and accessory phase chemistry to constraining basin development during post-collisional extension: a case study from the French Massif Central. Chemical Geology 201:319-336 
Burg JP, Brun JP, Van Den Driessche J (1990) Le sillon houiller du Massif Central français: faille de transfert pendant l'amincissement crustal de la chaîne. Comptes rendus de l'Académie des sciences. Série 2, Mécanique, Physique, Chimie, Sciences de l'univers, Sciences de la Terre 311:147-152

Burg JP, Van den Driessche J, Brun JP (1994) Syn-to post-thickening extension in the Variscan Belt of Western Europe: modes and structural consequences. Géologie de la France 3:33-51

Cartigny MJ, Ventra D, Postma G, and van Den Berg JH (2014) Morphodynamics and sedimentary structures of bedforms under supercritical-flow conditions: new insights from flume experiments. Sedimentology 61:712-748

Châteauneuf JJ, Farjanel G (1989) Synthèse géologique des bassins permiens français. Éditions du BRGM

Choulet F, Faure M, Fabbri O, Monié P (2012) Relationships between magmatism and extension along the AutunLa Serre fault system in the Variscan Belt of the eastern French Massif Central. International Journal of Earth Sciences 101: 393-413

Clarke JH, Brucker S, Muggah J, Hamilton T, Cartwright D, Church I, and Kuus P (2012) Temporal progression and spatial extent of mass wasting events on the Squamish prodelta slope. In: Landslides and engineered slopes: Protecting society through improved understanding. Taylor and Francis Group, London pp 1091-1096

Clarke JEH (2016). First wide-angle view of channelized turbidity currents links migrating cyclic steps to flow characteristics. Nature communications 7:1-13

Costa S, Rey P (1995) Lower crustal rejuvenation and growth during post-thickening collapse: Insights from a crustal cross section through a Variscan metamorphic core complex. Geology 23:905-908

Davies IC, and Walker RG (1974) Transport and deposition of resedimented conglomerates; the Cap Enrage Formation, Cambro-Ordovician, Gaspe, Quebec. Journal of Sedimentary Research 44:1200-1216

Debeglia N, Debrand-Passard S (1980) Principaux accidents tectoniques issus des corrélations entre les données de géophysique et les données de terrain (au sens large), dans le Sud-Ouest du bassin de Paris. Bulletin de la Société géologique de France 7:639-646

Delmas J, Houel P, Vially R (2002) Paris Basin, Petroleum potential. IFP regional Report

Dietrich P, Ghienne JF, Normandeau A, and Lajeunesse P (2016) Upslope-migrating bedforms in a proglacial sandur delta: cyclic steps from river-derived underflows? Journal of Sedimentary Research 86:112-122

Donsimoni M (1981) Synthèse géologique du bassin houiller lorrain. Mémoires du B.R.G.M., 117 
Donsimoni M (1990) Le gisement de charbon de Lucenay-lès-Aix (Nièvre). Documents du BRGM 179:84

Donsimoni, M. (2006) Le gisement de charbon de Lucenay-lès-Aix (Nièvre). Etat des connaissances acquises par le B.R.G.M. entre 1981 et 1986 - Rapport final - Projet nPDI06CDG54 (No. BRGM/RC-54694-FR). Rapports du B.R.G.M. Orléans.

Doubinger J, Elsass P (1979) Le bassin Permo-Carbonifère d'Autun. Nouvelles données stratigraphiques et palynologiques. Bulletin Trimestriel de la Société d'Histoire Naturelle et des Amis du Muséum d'Autun Autun 91:9-25

Ducassou C, Mercuzot M, Bourquin S, Rossignol C, Pellenard P, Beccaletto L et al. (2019) Sedimentology and $\mathrm{U}-\mathrm{Pb}$ dating of Carboniferous to Permian continental series of the northern Massif Central (France): Local palaeogeographic evolution and larger scale correlations. Palaeogeography, Palaeoclimatology, Palaeoecology 533:109228

Durand M (2006) The problem of the transition from the Permian to the Triassic Series in southeastern France: comparison with other Peritethyan regions. Geological Society, London, Special Publications 265:281-296

Elsass-Damon FE (1977) Les « schistes bitumineux » du bassin d'Autun : pétrographie, minéralogie, cristallochimie, pyrolyse. Dissertation, Université de Bourgogne

Faure M, Becq-Giraudon JF (1993) Sur la succession des épisodes extensifs au cours du désépaississement carbonifère du Massif Central français. Comptes rendus de l'Académie des sciences. Série 2, Mécanique, Physique, Chimie, Sciences de l'univers, Sciences de la Terre 316:967-973

Faure M (1995) Late orogenic carboniferous extensions in the Variscan French Massif Central. Tectonics 14:132153

Fielding CR, Frank TD, Isbell JL (2008) The late Paleozoic ice age - A review of current understanding and synthesis of global climate patterns. Resolving the late Paleozoic ice age in time and space 441:343-354

Franke W, Haak V, Oncken O, Tanner D (2000) Orogenic processes: quantification and modelling in the Variscan belt. Geological Society, London, Special Publications 179: 1-3

Gastaldo RA, DiMichele WA, Pfefferkorn HW (1996) Out of the icehouse into the greenhouse: a late Paleozoic analogue for modern global vegetational change. Gsa today 6:2-7 
Genna A, Roig JY, Debriette PJ, Bouchot V (1998) Le bassin houiller d'Argentat (Massif Central français), conséquence topographique d'un plissement de son substratum varisque. Comptes Rendus de l'Académie des Sciences-Series IIA-Earth and Planetary Science 327:279-284

Glennie KW, Higham J, Stemmerik L (2003) The Permian of the Northern North Sea. In Millennium Atlas: Petroleum Geology of the Central and Northern North Sea. Geological Society of London, pp. 91-103.

Grangeon M, Feys R, Greber CH, Lefavrais Raymond A (1968) Géologie profonde de la région de Decize (Nièvre). Essai de synthèse d'après les sondages profonds. Bull Bur Rech Géol Min 4:43-108

Heckel PH, Clayton G (2006) The Carboniferous System. Use of the new official names for the subsystems, series, and stages. Geologica acta 4:403-407

Isbell JL, Miller MF, Wolfe KL, Lenaker PA (2003) Timing of late Paleozoic glaciation in Gondwana: was glaciation responsible for the development of northern hemisphere cyclothems? Special papers-geological society of America 370:5-24

Langiaux J (1984) Flores et faunes des formations supérieures du Stéphanien de Blanzy-Montceau (Massif Central français) : stratigraphie et paléoécologie. Rev La Physiophile, Soc Et Sci Nat H ist Montceau 100:1-270

Lardeaux JM, Ledru P, Daniel I, Duchene S (2001) The Variscan French Massif Central—a new addition to the ultra-high pressure metamorphic 'club': exhumation processes and geodynamic consequences. Tectonophysics $332: 143-167$

Lebreton ML (1990) Les bassins stephano-permiens du sud du bassin de paris: controle structural et sedimentologique. Dissertation, University of Paris 11

López-Gamundí OR, Buatois LA (Eds.) (2010) Late Paleozoic glacial events and postglacial transgressions in Gondwana. Geological Society of America 468

Lotout C, Pitra P, Poujol M, Anczkiewicz R, Van Den Driessche J (2018) Timing and duration of Variscan highpressure metamorphism in the French Massif Central: A multimethod geochronological study from the Najac Massif. Lithos 308:381-394

Lowe D. R. (1982) Sediment gravity flows; II, Depositional models with special reference to the deposits of highdensity turbidity currents. Journal of sedimentary research 52:279-297 
Malavieille J, Guihot P, Costa S, Lardeaux JM, Gardien V (1990) Collapse of the thickened Variscan crust in the

French Massif Central: Mont Pilat extensional shear zone and St. Etienne Late Carboniferous basin. Tectonophysics 177:139-149

Martínez Catalán JR, Aller J, Alonso JL, Bastida F. (2009) The Iberian Variscan orogen. Spanish Geological Frameworks and Geosites: An Approach to Spanish Geological Heritage of International Relevance. IGME 13-27

Mascle, A. (1990). Géologie pétrolière des bassins permiens français. Comparaison avec les bassins permiens du Nord de l'Europe. Chronique de la recherche minière 499:69-86

Mathis V, Brulhet J (1990) Les gisements uranifères du bassin permien de Bourbon-l'Archambault (nord du Massif Central français). Chronique de la recherche minière 499:19-30

Matte P (1986) La chaîne varisque parmi les chaînes paléozoïques péri atlantiques, modèle d'évolution et position des grands blocs continentaux au Permo-Carbonifère. Bulletin de la Société géologique de France 2:9-24

McCann T, Pascal C, Timmerman MJ, Krzywiec P, López-Gómez J, Wetzel L et al. (2006) Post-Variscan (end Carboniferous-Early Permian) basin evolution in western and central Europe. Geological Society, London, Memoirs 32:355-388

Ménard G, Molnar P (1988) Collapse of a Hercynian Tibetan plateau into a late Palaeozoic European Basin and Range province. Nature 334:235-237

Menning M, Alekseev AS, Chuvashov BI, Davydov VI, Devuyst FX, Forke HC et al. (2006) Global time scale and regional stratigraphic reference scales of central and west Europe, east Europe, Tethys, south China, and North America as used in the Devonian-Carboniferous-Permian Correlation Chart 2003 (DCP 2003). Palaeogeography, Palaeoclimatology, Palaeoecology 240:318-372

Miall AD (1978) Tectonic setting and syndepositional deformation of molasse and other nonmarine-paralic sedimentary basins. Canadian Journal of Earth Sciences 15:1613-1632

Miall AD (1996) The Geology of Fluvial Deposits. Sedimentary Facies, Basin Analysis, and Petroleum Geology. Springer-Verlag, Berlin

Michel LA, Tabor NJ, Montañez IP, Schmitz MD, Davydov VI (2015) Chronostratigraphy and paleoclimatology of the Lodève Basin, France: evidence for a pan-tropical aridification event across the Carboniferous-Permian boundary. Palaeogeography, Palaeoclimatology, Palaeoecology 430:118-131 
Montañez IP, Tabor NJ, Niemeier D, DiMichele WA, Frank TD, Fielding CR et al. (2007) CO2-forced climate and vegetation instability during Late Paleozoic deglaciation. Science 315:87-91

Montañez IP, Poulsen CJ (2013) The Late Paleozoic ice age: an evolving paradigm. Annual Review of Earth and Planetary Sciences 41:629-656

Montañez IP, McElwain JC, Poulsen CJ, White JD, DiMichele WA, Wilson JP et al. (2016) Climate, pCO2 and terrestrial carbon cycle linkages during late Palaeozoic glacial-interglacial cycles. Nature Geoscience 9:824-828

Mulder T and Alexander J (2001) The physical character of subaqueous sedimentary density flows and their deposits. Sedimentology 48:269-299

Paquette JL, Ballèvre M, Peucat JJ, Cornen G (2017) From opening to subduction of an oceanic domain constrained by LA-ICP-MS U-Pb zircon dating (Variscan belt, Southern Armorican Massif, France). Lithos $294: 418-437$

Pellenard P, Gand G, Schmitz M, Galtier J, Broutin J, Stéyer JS (2017) High-precision U-Pb zircon ages for explosive volcanism calibrating the NW European continental Autunian stratotype. Gondwana Research 51:118136

Perrodon A, Zabek J (1990) Paris basin. Interior cratonic basins: AAPG Memoir 51:633-679

Pisarska-Jamroży M, Weckwerth P (2013) Soft-sediment deformation structures in a Pleistocene glaciolacustrine delta and their implications for the recognition of subenvironments in delta deposits. Sedimentology 60:637-665

Postma G (1984) Mass-flow conglomerates in a submarine canyon: Abrioja fan-delta, Pliocene, southeast Spain. Sedimentology of Gravels and Conglomerates Memoir 10:237-256

Postma G (1990) An analysis of the variation in delta architecture. Terra Nova 2:124-130

Postma G and Roep TB (1985) Resedimented conglomerates in the bottomsets of Gilbert-type gravel deltas. Journal of Sedimentary Research 55:874-885

Postma G, and Cartigny MJ (2014) Supercritical and subcritical turbidity currents and their deposits-A synthesis. Geology 42:987-990

Postma G, Kleverlaan K, and Cartigny MJ (2014) Recognition of cyclic steps in sandy and gravelly turbidite sequences, and consequences for the Bouma facies model. Sedimentology 61:2268-2290 
Rohais S, Eschard R, Ford M, Guillocheau F, Moretti I (2007) Stratigraphic architecture of the Plio-Pleistocene infill of the Corinth Rift: Implications for its structural evolution. Tectonophysics 440:5-28

Roscher M, Schneider JW (2006) Permo-Carboniferous climate: Early Pennsylvanian to Late Permian climate development of central Europe in a regional and global context. Geological Society, London, Special Publications $265: 95-136$

Rubi, R, Rohais S, Bourquin S, Moretti I, Desaubliaux G (2018) Processes and typology in Gilbert-type delta bottomset deposits based on outcrop examples in the Corinth Rift. Marine and Petroleum Geology 92:193-212

Schneider JW, Scholze F (2018) Late Pennsylvanian-Early Triassic conchostracan biostratigraphy: a preliminary approach. Geological Society, London, Special Publications 450:365-386

Schneider JW, Lucas SG, Scholze F, Voigt S, Marchetti L, Klein H, Opluštil S, Werneburg R, Golubev VK, Barrick JE, Nemyrovska T, Ronchi A, Day MO, Silantiev VV, Rößler R, Saber H, Linnemann U, Zharinova V, Shen S (2020) Late Paleozoic-early Mesozoic continental biostratigraphy-Links to the Standard Global Chronostratigraphic Scale. Palaeoworld 29:186-238

Scotese CR, Langford RP (1995) Pangea and the paleogeography of the Permian. In: The Permian of Northern Pangea. Springer, Berlin, Heidelberg, pp 3-19

Stampfli GM, Hochard C, Vérard C, Wilhem C (2013) The formation of Pangea. Tectonophysics 593: 1-19

Vallé B, Courel L, Gelard JP (1988) Les marqueurs de la tectonique synsédimentaire et syndiagénétique dans le bassin stéphanien à régime cisaillant de Blanzy-Montceau (Massif Central, France). Bulletin de la Société géologique de France 4:529-540

Van Den Driessche J, Brun JP (1989) Un modèle cinématique de l'extension paléozoïque supérieur dans le Sud du Massif Central. Comptes rendus de l'Académie des sciences. Série 2, Mécanique, Physique, Chimie, Sciences de l'univers, Sciences de la Terre 309:1607-1613

Van Den Driessche J, Brun J (1992) Structure and evolution of late Variscan extensional gneiss dome (Montagne Noire, southern Massif Central, France). Geodinamica Acta 5:85-99

Walker RG (1975) Generalized facies models for resedimented conglomerates of turbidite association. Geological Society of America Bulletin 86:737-748

\section{Figure captions}


Fig. 1 Localisation of the late Carboniferous to Permian basins in the north-eastern Massif Central (modified from Elsass-Damon 1977). The Lucenay-lès-Aix area is located south of the outcropping Decize-La Machine succession. AM: Armorican Massif; MC: Massif Central; P: Pyrenees; A: Alps; V: Vosges, AB: Aquitaine Basin, SEB: South-East Basin, PB: Paris Basin

Fig. 2 a. Map of the Lucenay-lès-Aix area, showing the location of the studied wells and the seismic lines. b. Synthetic sedimentary column, depositional environments evolution and stratigraphic cycles of the LY-F core after Ducassou et al. (2019). FP: floodplain; AF: alluvial-fan delta; Dfr: delta frontset; Dfo: delta foreset; Dbo: delta bottomset; L: lake; PL: playa lake

Fig. 3 Sedimentary logs of the LY-ZB (this study), LY-F (modified from Ducassou et al. 2019) and LY-G (this study) wells, with their respective depositional environment evolution. The log caption is available in Ducassou et al. (2019)

Fig. 4 Electrofacies and sedimentary facies correspondence for the alluvial plain, the volcaniclastic alluvial-fan delta, the delta and the lake environments. The sedimentary profile is from the LY-F well (Ducassou et al. 2019)

Fig. 5 Calibration of the depositional environments of the LY-I well based on well-log analyses

Fig. 6 A. Localisation of the seismic profiles and wells in the Lucenay-lès-Aix area. B. Calibration of the LY-F well-log along the LY-9 seismic profile. C. Interpretation of the seismic profiles LY-6, LY-5, LY-8 and LY-10

Fig. 7 Correlations based on seismic markers of the LY-ZB, LY-F, LY-D, LY-I and LY-G wells. When observed, the "Red Permian" is represented in red at the top of the wells

Fig. 8 Correlations between the LY-D, LY-U, LY-T and LY-L wells based on the seismic markers. When observed, the "Red Permian" is represented in red at the top of the wells

Fig. 9 Correlations between the LY-ZB, LY-F, LY-G and LY-Y wells based on seismic interpretations and stratigraphic cycles

Fig. 10 Correlations between the LY-U, LY-F and LY-I wells, showing the depositional environment variations in space and time

Fig. 11 Palaeogeographic maps showing the depositional environment evolution through time at the scale of the basin 
Fig. 12 Geographic map showing the proximity between the Decize-La Machine, Aumance, Autun and BlanzyLe Creusot basins. The distances between the Decize-la Machine Basin and the Autun and Blanzy-Le Creusot basins are indicated

Table 1 Facies description and interpretation of the depositional processes of the different studied wells, based on facies descriptions of Ducassou et al. (2019)

Table 2 Facies associations and their attribution to depositional environments based on facies associations determined by Ducassou et al. (2019)

Table 3 Illustrations of the main facies described in Table 1 and in the text. See Table 1 for the facies code. 